\title{
1 Water in volcanic glass: From volcanic degassing to secondary \\ 2 hydration
}

4 Angela N. Seligman ${ }^{a^{*}}$, Ilya N. Bindeman ${ }^{\text {a }}$, James M. Watkins a , Abigail M. Ross ${ }^{\text {a }}$

$5 \quad{ }^{a}$ Department of Geological Sciences, 1272 University of Oregon, Eugene, Oregon 97403-1272,

$6 U S A$

8 E-mail addresses:

9 seligman@uoregon.edu (A. N. Seligman)

10 bindeman@uoregon.edu (I. N. Bindeman)

11 watkins4@uoregon.edu (J. M. Watkins)

12 aross4@uoregon.edu (A. M. Ross)

*Correspondence:

15 Angela N. Seligman

16 Department of Geological Sciences

171272 University of Oregon

18 Eugene, OR 97403-1272

19 314-922-5293

\section{Abstract}

Volcanic glass is deposited with trace amounts (0.1-0.6 wt.\%) of undegassed magmatic water dissolved in the glass. After deposition, meteoric water penetrates into the glass structure mostly as molecular $\mathrm{H}_{2} \mathrm{O}$. Due to the lower $\delta \mathrm{D}(\%)$ values of non-tropical meteoric waters and the $\sim 30 \%$ offset between volcanic glass and environmental water during hydration, secondary water imparts lighter hydrogen isotopic values during secondary hydration up to a saturation concentration of 3-4 wt. \% $\mathrm{H}_{2} \mathrm{O}$. We analyzed compositionally and globally diverse volcanic glass from 0 to $10 \mathrm{ka}$ for their $\delta \mathrm{D}$ and $\mathrm{H}_{2} \mathrm{O}_{\mathrm{t}}$ across different climatic zones, and thus different $\delta \mathrm{D}$ of precipitation, on a thermal conversion elemental analyzer (TCEA) furnace attached to a mass spectrometer. We find that tephrachronologically coeval rhyolite glass is hydrated faster than basaltic glass, and in the majority of glasses an increase in age and total water content leads to a decrease in $\delta \mathrm{D}(\%)$, while a few equatorial glasses have little change in $\delta \mathrm{D}(\%)$. We compute a magmatic water correction based on our non-hydrated glasses, and calculate an average $10^{3} \ln \alpha_{\text {glass-water }}$ for our hydrated felsic glasses of $-33 \%$, which is similar to the $10^{3} \ln \alpha_{\text {glass-water }}$

35 determined by Friedman et al. (1993a). We also determine a smaller average $10^{3}$ ln $\alpha_{\text {glass-water }}$ for all our mafic glasses of $-23 \%$. We compare the $\delta \mathrm{D}$ values of water extracted from our glasses to local meteoric waters following the inclusion of our (and Friedman et al., 1993a) $-33 \%$ 
$10^{3} \ln \alpha_{\text {glass-water }}$. We find that, following a correction for residual magmatic water based on an average $\delta \mathrm{D}$ and wt. $\% \mathrm{H}_{2} \mathrm{O}_{\mathrm{t}}$ of recently erupted ashes from our study, the $\delta \mathrm{D}$ value of water extracted from hydrated volcanic glass is, on average, within $4 \%$ of local meteoric water. To better understand the difference in hydration rates of mafic and felsic glasses, we imaged 6 tephra clasts ranging in age and chemical composition with BSE (by FEI SEM) down to a

43 submicron resolution. Mafic tephra have lower vesicle number densities $\left(25-77 \mathrm{~mm}^{-2}\right)$ than felsic tephra $\left(736 \mathrm{~mm}^{-2}\right)$ and thicker average bubble walls $(0.07 \mathrm{~mm})$ than felsic tephra $(0.02$ $\mathrm{mm}$ ). We use a simplified diffusion model to quantify the hydration rate of vesicular glass as a function of the diffusivity of water and the average bubble wall thickness. Based on fits to our hydration rate data, we estimate the initial low-temperature diffusivity at $0.1 \mathrm{wt} . \% \mathrm{H}_{2} \mathrm{O}_{\mathrm{t}}$ in volcanic glass (mafic and felsic) to be on the order of $10^{-3}$ to $10^{-4} \mu^{2} / y e a r$ and find that differences in hydration rates between mafic and felsic tephra can be attributed primarily to differences in vesicularity, although slightly slower hydration of basalt cannot be precluded. We also observe no consistent temporal difference in secondary meteoric water uptake in wet versus dry and hot versus cold climates.

\section{$54 \quad$ Keywords}

55 secondary hydration, hydrogen isotopes, diffusion, water, paleoenvironments, Kamchatka

\section{INTRODUCTION}

Volcanic glass is widely used for paleoclimate studies due to its uptake of meteoric water

59 following deposition (Friedman et al., 1993b). This process is also known as secondary hydration 60 or 'rehydration'. The presence of environmental waters in volcanic glass has been used as a

61 tracer of the $\delta \mathrm{D}$ of local precipitation at the time of deposition (e.g. Riciputi et al., 2002; Mulch

62 et al., 2007; Cassel et al., 2014; Canavan et al., 2014), and the extent of hydration by meteoric

63 waters has been used to estimate the age of obsidian artifacts (e.g. Friedman et al. 1966; Anovitz

64 et al., 2004). However, volcanic glass can be deposited with unknown quantities of primary

65 magmatic water, which varies as a consequence of magmatic degassing processes (Newman et

66 al., 1988; Dobson et al., 1989; Castro et al., 2014). Both magmatic and meteoric water can have

67 distinct $\delta \mathrm{D}$ values (e.g. DeGroat-Nelson et al., 2001; Tuffen et al., 2010), depending on the $\delta \mathrm{D}$

68 value of the meteoric water that is diffusing into the glass, the degree of volcanic degassing that 
69 has occurred, and the original $\delta \mathrm{D}$ of the parental undegassed magma (Figs. 1-2). Therefore,

70 these two types of water can obscure each other in $\delta \mathrm{D}-\mathrm{H}_{2} \mathrm{O}$ space when they are both present in

71 volcanic glass, even though they could both provide useful information if the properties of one

72 can be known or constrained. Furthermore, the details of secondary hydration are not well

73 understood, and it is still unknown how long it takes for mafic and felsic glass to become

74 secondarily hydrated at surface temperature and pressure.

\section{1.1. Secondary hydration of volcanic glass}

77 Rehydration of degassed (primarily water-free) silicate glass is a complex process of

78 interface kinetics, water in-diffusion, and possibly minor re-speciation of hydrogen between

79 dissolved molecular water and hydroxyl groups (e.g. Zhang, 1999; Anovitz et al., 2008; Nolan

80 and Bindeman, 2013). The proposed models for rehydration range from a simple linear increase

81 to a square root of time dependence (e.g. Friedman et al., 1966; Nolan and Bindeman, 2013 and

82 references therein). Since the diffusion coefficients of water in glass are a strong function of

83 water concentration (Zhang and Behrens, 2000), hydration proceeds with a 'hydration front' that

84 has a relatively sharp interface, which is possible to observe under a microscope (Ross and

85 Smith, 1955; Friedman et al., 1966) and has therefore been used as a chronometer for dating.

86 Riciputi et al. (2002) used microscopic observations and SIMS depth profiling of ancient

87 obsidian artifacts of known age to quantify the distance of the hydration front ' $\mathrm{X}$ ' into volcanic

88 glass and determined that this distance $(X)$ is proportional to the sum of linear and square root

89 terms evaluated at time ( $t$ ) (e.g. Friedman et al. 1966; Anovitz et al., 2004):

$$
X \sim a t+b \sqrt{D t}
$$


91 where $a$ and $b$ are coefficients that depend on glass composition and climate, and $D$ is a water

92 concentration-dependent diffusion coefficient.

93 Secondary hydration of rhyolitic glass at ambient temperature and pressure is thought to

94 occur first through the exchange of hydrogen and deuterium ions with water soluble ions such as

$95 \mathrm{Na}^{+}, \mathrm{K}^{+}$, and $\mathrm{Ca}^{2+}$ and then by the absorption of $\mathrm{H}_{2} \mathrm{O}_{\text {mol }}\left(\right.$ molecular $\mathrm{H}_{2} \mathrm{O}$ ) (Jezek and Noble,

96 1978; Cerling et al., 1985; Oelkers, 2001; Rébiscoul et al., 2007; Valle et al., 2010). In contrast,

97 alteration of basaltic glass leads to the formation of palagonite-rich areas ( $10 \mathrm{wt} . \%$ water) on

98 the outer rind of the glass (Stroncik and Schmincke, 2002; Crovisier et al., 2003; Parruzot et al.,

99 2015). Although the hydration of mafic and felsic glass is different in some ways, previous work

100 by Crovisier et al. (2003), Cailleteau et al. (2008), and Valle et al. (2010) showed that during the

101 process of secondary hydration of both mafic and felsic volcanic glass, a thin (nanometers to

102 micrometers, depending on time) layer of maximally (4-5 wt. $\% \mathrm{H}_{2} \mathrm{O}_{\mathrm{t}}$ ) hydrated glass, or 'gel

103 layer', is formed on the surface of the glass. Increased densification, which leads to the closure

104 of pores, causes the gel layer to serve as a protective film, which decreases the rate of further

105 hydration of the glass interior. The formation of a gel layer is essential for studies involving

106 nuclear waste disposal, but a decrease, instead of a cessation, of alteration or hydration can still

107 be problematic for paleoenvironmental research that utilizes hydrogen isotopes, as was

108 demonstrated by Anovitz et al. (2009) and Nolan and Bindeman (2013).

109

110 1.2. Hydrogen isotopes in secondarily hydrated volcanic glass

111 Friedman et al. $(1966,1993 \mathrm{~b})$ first proposed that hydrogen isotopes in secondarily

112 hydrated ash and pumice could be used as a tool to monitor the $\mathrm{D} / \mathrm{H}$ of the original hydrating

113 water. Friedman et al. (1993a) showed that water uptake during rehydration results in an 
114 approximately -29 to $-31 \%$ offset between felsic glass and water (the glass being isotopically

115 lighter). Their experiments led to a semi-empirical fractionation factor of $\alpha_{\text {glass-water }}=0.9668 \pm$

$1160.0005\left(10^{3} \ln \alpha_{\text {glass-water }}\right.$ of $-34 \%$ o). Subsequent research (e.g. Shane and Ingraham, 2002; Mulch

117 et al., 2008; Cassel et al., 2014; Dettinger and Quade, 2015) has demonstrated that this

118 empirically derived fractionation factor does not vary significantly across different surface level

119 climatic conditions.

120 Recent studies have attempted to determine the reliability of the use of hydrogen isotopes

121 as a paleoenvironmental indicator. Anovitz et al. (2009) used polished obsidian surfaces and

122 isotopically labeled vapors to show that during secondary hydration at elevated temperature (150

$123{ }^{\circ} \mathrm{C}$ ), primary magmatic water dissolved in volcanic glass exchanges isotopically with secondary

124 water that diffuses into the glass. That is, any hydrogen already dissolved in the glass is not

125 strongly bound to the aluminosilicate matrix and is able to exchange and/or undergo further

126 diffusion into the glass. Subsequently, Nolan and Bindeman (2013) used long-term (3 years)

127 time series experiments at 70,40 , and $20{ }^{\circ} \mathrm{C}$ with natural ash from the already secondarily

128 hydrated 7.7 ka Mt. Mazama eruption to show that hydrogen isotopes equilibrate with

129 surrounding deuterated waters on a timescale of years for $70{ }^{\circ} \mathrm{C}$ and $40{ }^{\circ} \mathrm{C}$ experiments. While

130 hydrogen isotopes were able to readily exchange between ash and surrounding waters, the total

131 water concentration and the $\delta^{18} \mathrm{O}$ of the extracted water in the Nolan and Bindeman (2013)

132 experiments remained relatively constant and identical to the original water. These studies by

133 Anovitz et al. (2009) and Nolan and Bindeman (2013) indicate that once ash becomes

134 secondarily hydrated, its hydrogen isotopic ratio may be subject to change.

135

\section{1.3. Primary versus secondary waters in volcanic glass}


When relating $\mathrm{D} / \mathrm{H}$ and $\mathrm{H}_{2} \mathrm{O}_{\mathrm{t}}$ (total water including molecular and hydroxyl groups) in

138 secondarily hydrated tephra to ambient meteoric water, it is important to be able to estimate the

139 residual amounts of (isotopically distinct) primary magmatic water (Fig. 2). Thus, an inherent

140 difficulty exists in determining quantities of residual magmatic water left in volcanic glass, the

141 environmentally-added water, and how to distinguish between these two during analysis.

142 Furthermore, the potential exchange of hydrogen isotopes between the infiltrating secondary

143 waters and the original primary magmatic waters, as well as the changing $\mathrm{D} / \mathrm{H}$ of secondary

144 waters through time, could further complicate environmental signals.

145 It is thought that the major difference between magmatic and environmental water is that,

146 at low $\mathrm{H}_{2} \mathrm{O}_{\mathrm{t}}$ concentrations, magmatic water is predominantly in the form of dissolved $\mathrm{OH}^{-}$,

147 whereas environmental water is predominantly $\mathrm{H}_{2} \mathrm{O}_{\text {mol }}$ (e.g. Newman et al., 1986; Silver et al.,

148 1990; Giachetti et al., 2015). This is due to the higher energy, or temperature, needed for $\mathrm{H}_{2} \mathrm{O}_{\text {mol }}$

$149+\mathrm{O}^{2-}=2 \mathrm{OH}^{-}$respeciation to form $\mathrm{SiOH}$ bonds rather than hydrogen bonds that are formed

150 during the addition of $\mathrm{H}_{2} \mathrm{O}_{\text {mol. }}$ Investigation of water speciation and distinguishing between

151 different water types during progressive degassing creates potential opportunities to distinguish

152 between magmatic and meteoric water (Fig. 3). Giachetti et al. (2015) used the TGA

153 (Thermogravimetric Analysis) technique and compiled data for known water concentrations of

$154 \quad 0.0005-22.5 \mathrm{ka}$ intermediate to felsic volcanic glass ranging from approximately $0-4$ wt. $\% \mathrm{H}_{2} \mathrm{O}_{\mathrm{t}}$

155 to model the rate of secondary hydration of intermediate-felsic volcanic glass. They concluded

156 that, at surface temperatures, intermediate to felsic volcanic glass has a rehydration diffusivity of

157 approximately $10^{-23} \mathrm{~m}^{2} \mathrm{~s}^{-1}$ ( \pm approximately one order of magnitude), which is slightly slower

158 than previously determined diffusion rates for nuclear glasses at $50{ }^{\circ} \mathrm{C}$ of $10^{-21} \mathrm{~m}^{2} \mathrm{~s}^{-1}$ (Ferrand et

159 al., 2006). Giachetti et al. (2015) also numerically modeled TGA outputs to gain further insight 
160 into the process of secondary hydration through attempting to distinguish the difference in

161 magmatic and meteoric water in volcanic glass. As with any step heating technique, the

162 assumption is that secondary water $\left(\mathrm{H}_{2} \mathrm{O}_{\text {mol }}\right)$ is released at lower temperatures, while the more

163 strongly bound primary magmatic water $\left(\mathrm{OH}^{-}\right)$is released at higher temperatures. They showed

164 that the 1060 CE Glass Mountain rhyolitic pumices from California contain only small amounts

$165(0.2-0.5 \mathrm{wt} . \%)$ of residual primary magmatic water, and had 1-2 wt.\% meteoric water. In

166 addition, TGA coupled with FTIR (Fourier Transform Infrared) spectroscopy and D/H

167 determination of hydrous Mt. Mazama ash was used by Nolan and Bindeman (2013) to

168 understand proper heating temperatures to remove the most loosely bound adsorbed water on the

169 glass, and at what temperatures the most tightly bound, possibly magmatic water, is released.

170 These authors observed a progressive increase in $\mathrm{OH}^{-} / \mathrm{H}_{2} \mathrm{O}_{\mathrm{mol}}$ in the glass during heating and

171 dehydration, which potentially documented the release of secondary meteoric water as $\mathrm{H}_{2} \mathrm{O}_{\text {mol }}$

172 with low $\delta \mathrm{D}$ values. Importantly, the $\delta \mathrm{D}$ value of this progressively extracted water did not vary

173 significantly below $600{ }^{\circ} \mathrm{C}$. $\mathrm{High}^{-} \mathrm{OH}^{-} / \mathrm{H}_{2} \mathrm{O}_{\text {mol }}$ and higher $\delta \mathrm{D}$ values were observed within the

174 final $0.5 \mathrm{wt} . \% \mathrm{H}_{2} \mathrm{O}_{\mathrm{t}}$ at the end of step heating (above $600{ }^{\circ} \mathrm{C}$ ), which is interpreted to be primary

175 magmatic water.

176 Collectively, these studies demonstrate that it is possible to obtain an estimate of the

177 proportion of primary and secondary water in volcanic glass. It is not currently practical to

178 conduct experiments for measuring the hydration rate of glass at room temperature, due to the

179 very slow rates of secondary hydration (1-10 $\mu \mathrm{m} / 1000$ years; Friedman et al., 1966; this study,

180 see below). Below we attempt to further the understanding of secondary hydration at surface

181 temperatures through the use of hydrogen isotopes, total water concentration, and relative

182 vesicularities by using a natural experiment involving tephra of known ages. 


\section{$184 \quad$ 1.4. Goals of the present study}

185 Given the gaps in our understanding of the secondary hydration process, our research

186 questions include:

187 1) What is the rate of secondary hydration for mafic and felsic volcanic glass?

188 2) What causes the difference in hydration rates between mafic and felsic glass?

189 3) How do the isotopes of hydrogen $(\mathrm{D} / \mathrm{H})$ behave during secondary hydration?

190 4) What effect does the $\mathrm{D} / \mathrm{H}$ ratio of the residual primary magmatic water have on the

191 D/H ratio of the total water during analyses of volcanic glass?

192 5) Is the fractionation between meteoric water and water-in-glass the same for mafic and

$193 \quad$ felsic glasses?

194 To answer these questions, we use a series of natural volcanic tephra layers of known age

195 across different climates to provide insight into the secondary hydration process in terms of the

196 rates of secondary hydration and its isotopic signature (Table 1, Fig. 1). These volcanic tephra

197 layers from around the world cover a large range of $\delta \mathrm{D}_{\text {met }}(\delta \mathrm{D}$ of meteoric water) that also range

198 in age, chemical composition, water concentration $\left(\mathrm{H}_{2} \mathrm{O}_{\mathrm{t}}\right.$, wt.\%) and $\delta \mathrm{D}(\%)$. By utilizing

199 volcanic ash and tephra, we gain a wider range of data than would be possible through the use of

200 obsidian artifacts, and are able to compare our data to previously determined hydration rates of

201 obsidians (Riciputi et al., 2002; Eerkens et al., 2008). In addition, we focus on six tephra units

202 ranging from basalt to rhyolite that have different porosities, which we measure, to constrain the

203 influence of vesicularity and composition on the secondary hydration process. Using this

204 information, we then create simplified hydration models utilizing our water concentration and

205 age data to estimate the diffusivities for secondary hydration of felsic and mafic glass. 


\section{METHODS}

\subsection{Samples}

We use basaltic andesite scoria collected by us from Klyuchevskoy volcano in

210 Kamchatka, Russia, with ages ranging from 0.05-7.3 ka (Auer et al., 2009). This volcanic scoria

211 was used specifically due to the similar basaltic andesite composition of all samples collected

212 from the same trench across an approximately 7000 year time span (Ponomareva et al., 2007;

213 Auer et al., 2009; Ponomareva et al., 2013). Other mafic samples from Kamchatka include: the

2143.5 and 7.2 ka eruptions of Avachinsky volcano, the 7.5 ka eruption of Kizimen, the 0.05, 1.0,

2151.5 , and 2.8 ka eruptions of Shiveluch volcano, and the voluminous pyroclastic products from the

2167.6 ka caldera-forming eruption of Kurile Lake (Braitseva et al., 1997; Ponomareva et al., 2004;

217 Kyle et al., 2011). We also analyzed mafic samples from Tanzania that include the 2.0 and $4.0 \mathrm{ka}$

218 eruptions of Rungwe (Fontijn et al., 2010) (Tables 1-2; Fig. 1).

219 Felsic tephra samples were collected from Kamchatka, Chile, and the United States

220 (Tables 1-2; Fig. 1). The Kamchatka units include: the 7.9 ka eruption of Karymsky volcano, the

2211.8 and 6.4 ka eruptions of Ksudach volcano, the 7.6 ka eruption of Kurile Lake, the 0.3 and 3.5

222 ka eruptions of Opala volcano, the 7.0 ka eruption of Khangar volcano, and the 1.5 and $4.6 \mathrm{ka}$

223 Optr eruptions (Braitseva et al., 1997). Chilean units are from the: 10 ka Llaima, $3.0 \mathrm{ka}$

224 Sollipulli, and 4.5 ka Puyehue-Cordon Caulle eruptions (Fontijn et al., 2014). We also collected

225 multiple samples throughout Oregon from the $7.7 \mathrm{ka} \mathrm{Mt}$. Mazama eruption that formed Crater

226 Lake.

227 All samples analyzed in this study are $\leq 10,000$ years old. Based on their relatively

228 young, post-glacial Holocene ages, we assume that they are hydrated with meteoric water that 
229 has approximately similar $\delta \mathrm{D}$ to current precipitation. Therefore, all samples should be young

230 enough that the $\delta \mathrm{D}(\%)$ of the meteoric water hydrating them should not be significantly

231 changing on a millennial timescale (e.g. Henderson et al., 2010, which suggests 15-20\%o shifts

232 in $\delta$ D over the last 10,000 years).

\section{2.2. Hydrogen isotope and total water analyses of tephra and ash}

All volcanic glass samples from this study were analyzed for both $\delta \mathrm{D}$ and $\mathrm{H}_{2} \mathrm{O}_{\mathrm{t}}$ on the

236 TCEA (Thermal Conversion Elemental Analyzer) continuous flow and sampling system at the

237 University of Oregon stable isotope laboratory (e.g. Bindeman et al., 2012). Prior to analysis,

238 tephra samples were lightly crushed, placed in a water-filled beaker, and sonicated for $\sim 60 \mathrm{~min}$

239 to remove any clays that, if present, may be attached to the glass. The samples were then dried

240 and individual glass shards smaller than $\sim 0.5 \mathrm{~mm}$ were picked under microscope to ensure that

241 the glass was pristine. We first experimented with pretreating samples with $8 \% \mathrm{HF}$ twice for 30

242 seconds (Cerling et al., 1985; Sarna-Wojcicki and Davis, 1991; Cassel et al., 2012), but found

243 that such a procedure yields greater scatter (Fig. A1) and abandoned this approach because our

244 samples are fresh and do not contain any secondary 'gel' layer as for the above-mentioned

245 studies. Our results, which are similar to those from Dettinger and Quade (2015) that show glass

246 samples pretreated with HF having variable $\delta \mathrm{D}$ effects in glass that are not well understood, we

247 chose not to pretreat any samples in $8 \%$ HF. Following sample preparation, $2-12 \mathrm{mg}$ of glass

248 (depending on the expected water content, where the lowest water content samples need the

249 largest mass of glass) were picked using a binocular microscope and packaged in silver foil. Ash

250 samples were sieved to keep the 50-250 $\mu \mathrm{m}$ size fraction, as demonstrated by experimentation

251 with glass standards to yield the best reproducibility (Bindeman et al., 2012). Some ash samples 
252 contain too many small phenocrysts (microphenocrysts or microlites) to be completely separated

253 from the glass. For these samples, a modal percent of minerals was approximated, and the wt.\%

$254 \quad \mathrm{H}_{2} \mathrm{O}_{\mathrm{t}}$ was corrected following the analysis (Table 3). These small phenocrysts were all

255 determined to be anhydrous, so a correction was only needed for the wt. $\% \mathrm{H}_{2} \mathrm{O}_{t}$ and not for the

$256 \delta \mathrm{D}$ value. Prior to analysis, all samples were heated in a vacuum-sealed oven overnight at $130{ }^{\circ} \mathrm{C}$

257 to remove any adsorbed waters on the outer surface of the glass (e.g. Nolan and Bindeman,

258 2013). Samples were then immediately loaded into a TCEA autosampler (typically within 10-15

$259 \mathrm{~min}$ ), where they were purged with He carrier gas.

260 The first part of this study included standardization using three mica reference standards

261 during each set of analyses (NBS30 biotite, $\delta \mathrm{D}=-65.7 \%$, and two other in house standards

262 calibrated relative to NBS30 in three other labs: BUD Butte (MT) quartz monzonite biotite, $\delta \mathrm{D}=$

$263-161.8 \%$, and RUH2 muscovite, $\delta \mathrm{D}=-98.2 \%$ ), which nearly span the range of our unknowns.

264 Following each set of analyses, a three point calibration using the offsets between the measured

265 and nominal $\delta \mathrm{D}$ values for the mica standards was performed to correct for day-to-day analytical

266 variations in $\delta \mathrm{D}$ values. These same analyses were also used to determine the total water content

267 in the glass. NBS30, with a known wt. $\% \mathrm{H}_{2} \mathrm{O}_{\mathrm{t}}$ of 3.5 was used as a standard for water

268 concentration corrections.

269 In order to present our results relative to VSMOW, we ran glass samples in the latter part

270 of this study against water (VSMOW, W62001, and GISP) sealed in silver cups (Qi et al., 2010).

271 This extra step was necessary due to a recent study by Qi et al. (2014), which demonstrated that

272 the NBS30 nominal $\delta \mathrm{D}$ value is $15-21 \%$ heavier than previously proposed. We therefore ran all

273 of our mica standards (NBS30, BUD, and RUH2) directly against these waters sealed in silver

274 cups, which have $\delta \mathrm{D}$ values spanning the relevant $\delta \mathrm{D}$ range of our solids. This was done to 
275 calibrate the $\delta \mathrm{D}$ of water extracted from the micas for our lab specifically relative to a water-

276 based VSMOW scale. For further information on the correction of the NBS30 standard, see Qi et

277 al. (2014), which is what we base our lab specific corrections on. Through seven different

278 analytical sessions of calibration between our mica standards and the three water standards, we

279 obtain a conversion equation of: $\delta D_{\text {mica corrected }}=0.9888 \delta D_{\text {initial }}+15.385$, with an $\mathrm{R}^{2}$ of

280 0.99179. We use this conversion equation to correct all of our mica data, which provided a

281 correction of $+16-17 \%$ to our old mica-based normalization, depending on the $\delta \mathrm{D}$ value. The

282 data below are all reported with respect to the water standards we utilize in this study (VSMOW,

283 GISP, and W62001).

2.3. SEM imaging of volcanic tephra to determine surface to volume ratios and bubble wall

286 thicknesses

Six tephra units shown in Table 4 with known water content and $\delta \mathrm{D}$ were imaged with

288 Back-Scattered Electrons (BSE). These tephra were chosen to provide a range of vesicularity and

289 bubble wall thickness for mafic units of various ages from the same volcano (Klyuchevskoy), as

290 well as for a range in compositions from the same compositionally diverse eruption (Kurile

291 Lake). These six tephra were photographed under high magnification using a FEI Quanta 200

292 SEM microscope at $20 \mathrm{keV}$, allowing sub-micron resolution (Fig. 4). The photographs were

293 converted to black and white in Adobe Photoshop and checked to make sure all black regions

294 were vesicles (Fig. 5). If they were not, they were changed to white, and vice versa. A separate

295 image was then created so that the entire tephra clast, including vesicles, was all one color. This

296 allowed for the entire area of the tephra clast and vesicles to be determined. Another image was

297 created with just the minerals shown in black, so these areas could be removed from any 
298 subsequent calculations. All images were imported into the image-processing program NIH

299 ImageJ, which was used to determine the number of vesicles, the area of each vesicle, the

300 perimeter of each vesicle, the total area of the tephra clast including the vesicles and the glass,

301 and the area of the minerals (Fig. 6). The perimeter of each vesicle was assumed to create a

302 circle, and the radius of each vesicle was calculated from: $R=\frac{P}{2 \pi}$, where $R$ is the radius of the

303 assumed circle in $\mathrm{mm}$ and $P$ is the perimeter in mm. Following Giachetti and Gonnermann

304 (2013), we assumed that the vesicles are distributed evenly across the tephra clast (i.e., we use

305 the hexagonal close-packing assumption of Princen (1979) and Proussevitch et al. (1993)) and

306 estimated the average bubble wall thickness for each tephra clast using the equation: $S=\frac{R}{\phi^{\frac{1}{3}}}$,

307 where $S$ is the average thickness of the bubble wall in $\mathrm{mm}, \phi$ is the vesicularity, and $R$ is again

308 the radius in mm. As a check, these values were compared to the SEM tephra clast images (Figs.

309 4-6) to ensure that they are indeed reasonable.

310

311 3. RESULTS

312 We report data from Holocene ash and tephra and provide a range of water

313 concentrations and $\mathrm{D} / \mathrm{H}$ from $0-10$ ka volcanic glass of both mafic and felsic composition to

314 better understand hydration rates and corresponding $\mathrm{D} / \mathrm{H}$ trends with secondary hydration.

316 3.1. Water concentration and hydrogen isotopes in felsic and mafic ashes and scoria

317 3.1.1. Recently deposited felsic ash samples

318 The recently deposited ash from the 1992 eruption of Mt. Spurr (42-Cordova and 57-

319 Ashton), the 1974 eruption of Volcán de Fuego (VF-74-45 and VF-74-200), and the 2014

320 eruption of Kelud (Margomulyo-1p and Campling-4p) are used to gain a better understanding of 
321 the quantity of residual undegassed magmatic water dissolved in the glass that volcanic ash is

322 deposited with, and the $\delta \mathrm{D}$ of these associated dissolved waters. These glasses were all collected

323 either during or recently following eruption, so they are assumed to contain only magmatic

324 water, and provide a constraint on the $\mathrm{H}_{2} \mathrm{O}_{t}$ and $\mathrm{D} / \mathrm{H}$ of primary magmatic water. These data plot

325 within the magmatic degassing trend in Figure 2. The $\mathrm{H}_{2} \mathrm{O}_{t}$ of these samples ranges from 0.1-0.6

326 wt. $\% \mathrm{H}_{2} \mathrm{O}_{\mathrm{t}}$ and the $\delta \mathrm{D}$ ranges from -69 to $-93 \%$.

\subsubsection{Mass balance relations}

Results above indicate that unaltered volcanic ash can contain as much as $~ 0.6 \mathrm{wt} . \%$

330 magmatic water. Although these quantities vary from one tephra layer to the next $(0.1-0.6$

331 wt. \%), the average water content is $0.3 \mathrm{wt} . \%$. With these data, we can account for the influence

332 of primary magmatic water using mass balance equations:

$$
\mathrm{H}_{2} \mathrm{O}_{t}=\mathrm{H}_{2} \mathrm{O}_{t, m e t}+\mathrm{H}_{2} \mathrm{O}_{t, \mathrm{mag}}
$$

333

$$
\delta D_{t} \approx F_{\text {met }}\left(\delta D_{\text {met }}-\Delta_{\text {water-glass }}\right)+\left(1-F_{\text {met }}\right)\left(\delta D_{\text {mag }}\right)
$$

335 where $F$ is the fraction by weight of water in glass that is meteoric, t,met designates the total 336 secondary meteoric water (hydroxyl and molecular), t,mag designates the total primary

337 magmatic water, and $\Delta_{\text {water-glass }}$ is equal to $\delta_{\text {water }} \delta_{\text {glass }}$. These mass balance equations describe the 338 variations between the quantity of residual magmatic water left in the glass following deposition, 339 and the relative quantity of secondary hydration. This relation is illustrated in Figure 7, which 340 shows the effect that residual magmatic water can have on the total $\delta \mathrm{D}$ values during analysis of 
341 the glass, indicating a need for a correction for primary magmatic water during $\delta \mathrm{D}$ analyses of

342 hydrated volcanic glass, which will be discussed further below.

344 3.1.3. Hydration of mafic glass

345 Water concentrations versus the ages of volcanic scoria from Klyuchevskoy volcano

346 show that there is a general trend of slightly increasing wt. $\% \mathrm{H}_{2} \mathrm{O}_{\mathrm{t}}$ and decreasing $\delta \mathrm{D}(\%$ ) with

347 age (Figs. 8, A2). The youngest samples, with ages younger than $\sim 0.2 \mathrm{ka}$, have $\sim 0.4$ wt. $\% \mathrm{H}_{2} \mathrm{O}_{\mathrm{t}}$

348 on average. The older samples, ages 4.7 to $7.3 \mathrm{ka}$, have slightly higher water concentrations

349 ( 0.4 to 1.0 wt.\%). Given the low $\delta \mathrm{D}$ of precipitation in Kamchatka (-136\%; interpolated value

350 from Bowen, 2015; Bowen and Revenaugh, 2003), the decrease in $\delta \mathrm{D}$ with increasing age and

351 water content is an isotopic indication of minor secondary hydration.

352 In addition to the stratigraphic sequence of the Klyuchevskoy scoria, we analyzed mafic

353 tephra $\left(\leq 63\right.$ wt.\% $\left.\mathrm{SiO}_{2}\right)$ with a range in age and water concentrations from around Kamchatka

354 and Tanzania to obtain further hydration and $\delta \mathrm{D}$ trends of mafic tephra worldwide (Tables 1-2;

355 Fig. 1). Although the majority of these tephra were more hydrated than the Klyuchevskoy scoria,

356 their water contents generally do not exceed $2.0 \mathrm{wt} . \% \mathrm{H}_{2} \mathrm{O}_{\mathrm{t}}$, even for the tephra that are up to 7.6

357 ka. Only three glass samples have higher water concentrations: the 2.0 and 4.0 ka eruption of

358 Rungwe and the 7.5 ka eruption of Kizimen. The trend of decreasing $\delta \mathrm{D}(\%)$ with increasing

359 wt. $\%$ of added secondary $\mathrm{H}_{2} \mathrm{O}_{\mathrm{t}}$ is most clear up to $\sim 1.5$ wt. $\% \mathrm{H}_{2} \mathrm{O}_{\mathrm{t}}$, after which the $\delta \mathrm{D}$ values

360 become more scattered $(-129--73 \%)$. This is likely due to the differing $\delta \mathrm{D}$ of local meteoric

361 water, as the scatter is mostly due to the hydrated Tanzania samples from a lower latitude, where

362 we see $\delta \mathrm{D}$ of precipitation that is near $100 \%$ heavier than at the higher latitude regions. (Figs.

363 1-2). 


\section{3.1.5. Hydration of felsic glass}

$366 \quad$ Felsic tephra from varying climates all show a clear trend of increasing water and

367 decreasing $\delta \mathrm{D}$ within the first 1500 years, when compared to the recently deposited tephra (Fig.

368 8). Water concentrations of the felsic glasses have $\sim 0.5 \mathrm{wt} . \% \mathrm{H}_{2} \mathrm{O}_{\mathrm{t}}$ at 300 years and have up to

$369 \sim 3.0$ wt. $\% \mathrm{H}_{2} \mathrm{O}_{\mathrm{t}}$ after 2700 years (Fig. 8). After $\sim 2700$ years, the water content generally stays

370 near or above $\sim 2.0$ wt. $\%\left( \pm 1.0 \mathrm{wt} . \% \mathrm{H}_{2} \mathrm{O}_{\mathrm{t}}\right)$. This is in exception to three of the Mt. Mazama

371 glass samples, which have higher $\mathrm{H}_{2} \mathrm{O}_{t}$ between 4.0 and 5.0 wt.\% (Figs. 2, 8). Besides the recent

372 ash, the youngest felsic glass analyzed here is the 300 year old Opala ash from Kamchatka with

3730.5 wt. $\% \mathrm{H}_{2} \mathrm{O}_{\mathrm{t}}$, which is on the higher end of undegassed water concentrations of the recently

374 deposited ash described above. At higher water contents ( 2.0 to 3.5 wt. $\% \mathrm{H}_{2} \mathrm{O}_{\mathrm{t}}$ ), we observe a

375 large range of $\delta \mathrm{D}$ values ( -147 to $-95 \%)$, which is again a reflection of the range in $\delta \mathrm{D}(\%)$ of

376 precipitation around the world (Figs. 1-2).

\subsection{Surface area as determined by SEM images of basalt versus rhyolite tephra}

We examined clast textures and differences in surface areas of mafic versus felsic tephra

380 on BSE images. The basalt-basaltic andesite units from Kurile Lake and Klyuchevskoy have the

381 lowest number density of vesicles $\left(25-77 \mathrm{~mm}^{-2}\right)$. Furthermore, the Klyuchevskoy basaltic

382 andesites consistently have lower vesicle number densities $\left(25-72 \mathrm{~mm}^{-2}\right)$ than all the Kurile Lake

383 tephra clasts. The andesite from the Kurile Lake eruption has a moderate number density (161

$384 \mathrm{~mm}^{-2}$ ) and the rhyolite from the Kurile Lake eruption has the highest density of vesicles (736

$385 \mathrm{~mm}^{-2}$ ) (Table 4). Similarly, the rhyolite tephra has the smallest average bubble wall thickness 
$386(0.02 \mathrm{~mm})$, while the average bubble wall thickness for the basalt and basaltic andesites is 0.07

$387 \mathrm{~mm}$.

389 4. DISCUSSION

\section{$390 \quad 4.1$ Mass balance analysis in distinguishing between magmatic and meteoric water}

The importance of creating a magmatic water correction to better obtain the meteoric

392 water $\delta \mathrm{D}$ signal is illustrated in Figure 7. The wt.\% residual $\mathrm{H}_{2} \mathrm{O}_{\mathrm{t}}$ and $\delta \mathrm{D}$ values are likely

393 different at each volcano, so the magmatic correction needed for each volcano is likely different

394 (and can be independently estimated using the youngest deposits), but we assume that similar

395 looking tephra layers in the same section from a single volcano, such as Klyuchevskoy, can have

396 identical residual $\mathrm{H}_{2} \mathrm{O}_{\mathrm{t}}$ and $\delta \mathrm{D}$. To define a correction to remove the $\delta \mathrm{D}(\%)$ value of the

397 primary magmatic water, we took an average $\delta \mathrm{D}(\%)$ and $\mathrm{H}_{2} \mathrm{O}_{\mathrm{t}}(\mathrm{wt} . \%)$ of the mafic tephra that

398 have ages less than or equal to $1.0 \mathrm{ka}$ and $\mathrm{H}_{2} \mathrm{O}_{\mathrm{t}}$ below $0.6 \mathrm{wt} . \%$. The water concentration limit is

399 based on the highest water concentration of the recently erupted ash (Mt. Spurr) and an age limit

400 that is based on the low water concentration and high $\delta \mathrm{D}$ that we see for ash samples less than

4011000 years old, indicating a lack of secondary hydration in these tephra. This provides an

402 average $\delta \mathrm{D}$ and $\mathrm{H}_{2} \mathrm{O}_{\mathrm{t}}$ for nine degassed tephra of $-83 \%$ ( $\pm 7.7,1 \square$.d.) and 0.32 wt. $\%( \pm 0.2,1$

$403 \square$. d.), respectively. Since we have a series of tephra from Klyuchevskoy volcano, we created a

404 separate correction for the two Klyuchevskoy glasses of $-86 \% \delta \mathrm{D}( \pm 2.2,1 \square$. d.) and 0.35 wt. $\%$

$405 \mathrm{H}_{2} \mathrm{O}_{\mathrm{t}}( \pm 0.1,1 \square$. d. $)$, which was determined by the two youngest Klyuchevskoy units $(0.05$ and

$4061.0 \mathrm{ka}$ ). Six basalt-basaltic andesite units are older than $1.0 \mathrm{ka}$, but have less total water than the

407 correction factor (7.6 ka Kurile Lake, 3.5 ka Avachinsky, 2.3 ka Klyuchevskoy, 2.7 ka

408 Klyuchevskoy, 2.8 ka Klyuchevskoy, 3.6 ka Klyuchveskoy). These units with low water 
409 concentrations are assumed to contain only primary magmatic water and were excluded from

410 further analysis of secondary water determination when using the correction.

\section{$412 \quad 4.2 \delta \mathrm{D}$ trends of secondary hydration as compared to local $\delta \mathrm{D}$ of precipitation}

413 We compare the $\delta \mathrm{D}(\%)$ of the water in our glasses to local $\delta \mathrm{D}(\%)$ of meteoric waters,

414 while taking into account the 0.9668 fractionation between meteoric water and water in volcanic

415 glass, where glass is depleted in deuterium (Friedman et al., 1993a) (Fig. 9). Furthermore, we

416 initially use the fractionation factor determined by Friedman et al. (1993a), which is intended for

417 felsic glasses, on mafic glasses, and compare them to local meteoric waters to see if the

418 fractionation factor is similar for mafic glasses, which is discussed further below. We also take

419 into account our correction for total water and $\delta \mathrm{D}$ of primary magmatic water in this section, and

420 do not discuss the isotopic characteristics of samples with water contents equal to or less than the

421 magmatic water correction.

422 Prior to a magmatic water correction, our $\delta \mathrm{D}_{\text {glass }}$ values are typically heavier than their

423 associated local meteoric waters (Fig. 9a, 10a). This can be explained if the water is mostly

424 magmatic, as is illustrated in Figures 2 and 7, since magmatic water remaining in the glass is

425 commonly heavier in $\delta \mathrm{D}$ than the local meteoric water at higher latitudes (Fig. 1). This is

426 particularly characteristic for many of the recently erupted ash and scoria samples with only

427 magmatic water present in them that do not fall on the 1:1 line (Fig. 9a). The only exceptions are

428 the glasses from Volcán de Fuego and Kelud, which both fall near the 1:1 line and are both

429 located near the equator (Fig. 1). They therefore have heavier local precipitation $\delta \mathrm{D}(\% 0)$ similar

430 to the range of $\delta \mathrm{D}(\%)$ values of mostly degassed magmas (Figs. 2, 9a). Thus, as is illustrated in

431 Figure 2, the two types of water mask each other. The recent ash that is far from the 1:1 line is 
432 from the Alaskan Mt. Spurr, which is located at a northern latitude (Fig. 1), and therefore has

433 local $\delta \mathrm{D}(\%)$ values of precipitation that are significantly lighter than average degassed magmas.

434 This is also true for all Holocene Kamchatkan scoria and ash studied by us (Figs. 1, 9a, 10a).

435 After applying the magmatic water correction, the mafic glasses fall within an average of $13 \%$

436 of the 1:1 line, now deviating an average of $43 \%$ less from the 1:1 line than they did prior to the

437 magmatic water correction (Figs. 9-10). It should be noted that deviations from the 1:1 line also

438 reflect our choice of $\delta \mathrm{D}$, which we took from a global dataset rather than year-long averaged

439 measurements that would have been more appropriate in this case, which is still possible to do in

440 the future.

441 A natural experiment of secondary hydration of basaltic tephra is provided by the $\delta \mathrm{D}$

442 values of multiple tephra layers from Klyuchevskoy volcano in Kamchatka (0.05-7.3 ka), which

443 lie above the 1:1 line prior to any magmatic water correction (Fig. 9a). Despite the fact that the

444 majority of the water in the Klyuchevskoy glasses is higher $\delta \mathrm{D}$ undegassed magmatic water, we

445 observe that the total water is increasing slightly, and the $\delta \mathrm{D}(\%)$ values are gradually decreasing

446 with the increasing age of the tephra (Figs. 8, A2). This indicates a slow process of rehydration

447 of up to $0.6 \mathrm{wt} . \% \mathrm{H}_{2} \mathrm{O}_{\mathrm{t}}$ at $7.3 \mathrm{ka}$. After applying the correction, there is an average of $60 \%$ less

448 deviation from the 1:1 line (Fig. 9b).

449 Water extracted from the postglacial $7.7 \mathrm{ka}$ Mt. Mazama glasses and other Holocene

450 felsic glass $(0.3-10 \mathrm{ka})$ are, on average, within $\sim 15 \%$ of the $1: 1$ line prior to the magmatic water

451 correction (Fig. 9a). Following the magmatic water correction, the data are within an average of

$4524 \%$ of the 1:1 line. The lesser improvement in fit (although still significant) between the mafic

453 and felsic samples is due to the difference in percentage of magmatic water, where the mafic

454 tephra have a higher percentage of magmatic water than the secondarily hydrated felsic tephra. 
455 Although the improvement is smaller in the felsic samples, the magmatic water correction still

456 creates an improvement in the correlation between the water in the glass and the surrounding

457 meteoric water (Figs. 9, 10).

458 When splitting the glass samples into low water concentration $\left(<1.5 \mathrm{wt} . \% \mathrm{H}_{2} \mathrm{O}_{\mathrm{t}}\right)$ and high

459 water concentration ( $\left.>1.5 \mathrm{wt} . \% \mathrm{H}_{2} \mathrm{O}_{\mathrm{t}}\right)$ sets, there was an average of $46 \%$ less deviation from the

460 expected $\delta \mathrm{D}_{\text {met }}$ value for the low water concentration samples and an average of $7 \%$ less

461 deviation for the high concentration samples following the correction. This separation of water

462 concentrations is also nearly represented by a separation of mafic versus felsic glasses, where

463 only one rhyolite fell into the low water category ( $0.3 \mathrm{ka}$ Opala) and three andesites (Rungwe

464 and Kizimen) fell into the high water category, due to the tendency for rhyolites to become

465 hydrated more rapidly.

466

467 4.2.1 Fractionation between meteoric water and volcanic glasses of mafic and felsic composition

468 We compare the $\mathrm{D} / \mathrm{H}$ of water from our analyses to the local $\mathrm{D} / \mathrm{H}$ of precipitation for

469 each glass to calculate the fractionation between meteoric water and mafic and felsic glasses in

470 varying climatic regions (Fig. A3). To do this, we utilize our magmatic corrected $\delta \mathrm{D}$ values and

471 compare these values to the local $\delta \mathrm{D}$ of precipitation from Bowen and Revenaugh (2003) and

472 Bowen (2015). We conduct this exercise separately for mafic and felsic glasses, and also for

473 regions with different climates (hot/cold and wet/dry). We report fractionations as $10^{3} \ln \alpha_{\text {glass- }}$

474 water, where:

$$
\alpha_{\text {glass-water }}=\frac{\left(1000-\delta D_{\text {glass }}\right)}{\left(1000-\delta D_{\text {water }}\right)}
$$


476 glass designates the $\mathrm{D} / \mathrm{H}$ ratio of water extracted from volcanic glass and water designates the

$477 \mathrm{D} / \mathrm{H}$ ratio of liquid meteoric water.

478 We determine an average global $10^{3} \ln \alpha_{\text {glass-water }}$ of $-33 \%( \pm 15 \%$; $1 \square \square$.d.) for all our

479 hydrated felsic glasses, in which we include glasses older than 2.0 ka with water concentrations

480 greater than $1.5 \mathrm{wt} . \%$ (Fig. A3). This value is similar to the $10^{3} \ln \alpha_{\text {glass-water }}=-34 \%$ from

481 Friedman et al. (1993a), and illustrates the kinetic fractionation that occurs during the addition of

482 water into volcanic glass, where the lighter isotope (hydrogen) diffuses faster than the heavier

483 isotope (deuterium). However, it is curious that Friedman et al. (1993a) did not conduct a

484 magmatic correction on their glasses. Their method, however, utilized water contained within

485 hydrated glass spheres from volcanic eruptions, and compared the $\delta \mathrm{D}$ of the liquid water within

486 the hollow sphere (presumed to represent environmental water) to the $\delta \mathrm{D}$ of the water extracted

487 from the glass to determine their $10^{3} \ln \alpha_{\text {glass-water }}$ Their difference in methodology leads to

488 differing assumptions and causes our comparisons to become difficult. If we include all felsic

489 glasses, except those used in the magmatic water correction, the $10^{3} \ln \alpha_{\text {glass-water }}$ is slightly smaller

490 at $-31 \%$ ( $\pm 16 \%$; $1 \square \square$.d.). Figure A3 also illustrates the $10^{3} \ln \alpha_{\text {glass-water }}$ of $-20 \% 0( \pm 17 \%$; 1

$491 \square$. d.) for all our felsic glasses prior to the magmatic correction, which does not agree with the

$49210^{3} \ln \alpha_{\text {glass-water }}$ of Friedman et al. (1993a). We also find variations in the $10^{3} \ln \alpha_{\text {glass-water }}$ value

493 when we split these same data up into separate climatic regions. The average $10^{3} \ln \alpha_{\text {glass-water }}$ for

494 the cold and wet climate of Kamchatka (MAT of $\sim 5^{\circ} \mathrm{C}$ and average annual precipitation of $495 \sim 1000 \mathrm{~mm})$ is $-20 \%$ ( $\pm 11 \%$; $1 \square \square$.d.). The average $10^{3} \ln \alpha_{\text {glass-water }}$ for the warm and wet 496 climate of Chile (MAT of $\sim 11{ }^{\circ} \mathrm{C}$ and annual precipitation of $\sim 2000 \mathrm{~mm}$ ) is $-50 \%$ ( $\pm 2 \%$;

$4971 \square \square$. d.). We also include the Pacific Northwest of the United States (Mt. Mazama pumices), 498 which cover a range of climatic settings. Most of the pumices were collected near Crater Lake 
499 National Park, which is located in a cold $\left(\sim 8{ }^{\circ} \mathrm{C}\right.$ MAT) and wet ( 1000 mm annual precipitation)

500 environment. The average $10^{3} \ln \alpha_{\text {glass-water }}$ for these pumices is $-37 \%$ ( $\pm 15 \%$; $1 \square \square$.d. $)$. Two of

501 the Mt. Mazama samples were collected farther to the east (Mazama-WMC, 2014MM-1), in a

502 dryer setting ( $\sim 300 \mathrm{~mm}$ annual precipitation), and yield an average $10^{3} \ln \alpha_{\text {glass-water }}$ of $-29 \%$ ( $( \pm 28$

$503 \%$; 1 $\square \square$.d.). Although we find a similar average fractionation to Friedman et al. (1993a) for all

504 of our tephra, we observe a large variation in our $10^{3} \ln \alpha_{\text {glass-water }}$ averages, represented here as

505 large standard deviations. In addition, counter to what would be expected, we see larger

506 fractionations in warm and wet settings, although we only have 3 samples from a warm and wet

507 region, and two from a dry region, which are not significant enough to build a final conclusion.

508 Our global data set for the hydrated mafic glasses is significantly smaller than that for the

509 felsic glasses (Fig. A3). If we only include glasses with >1.5 wt. \% $\mathrm{H}_{2} \mathrm{O}_{\mathrm{t}}$ that are older than 2000

510 years, we have just three glasses to create our average $10^{3} \ln \alpha_{\text {glass-water }}$ of $-45 \%$ ( $\pm 27 \%$;

511 1 $\square \square$.d.). We do not consider three glasses significant enough to make a final conclusion on

512 mafic fractionations. Our global average for all mafic glass $10^{3} \ln \alpha_{\text {glass-water }}$ is $-23 \%$ ( $\pm 23 \%$;

$5131 \square \square . d$.), which is smaller than our (and Friedman et al., 1993a) estimate for the felsic

$51410^{3} \ln \alpha_{\text {glass-water }}$ Unlike for the felsic glasses, we find the $10^{3} \ln \alpha_{\text {glass-water }}$ of the larger data set of

515 the mafic glasses that has been corrected for residual magmatic water to be more robust. This is

516 due to there being only a few hydrated mafic glasses in this study. If we determine the

$51710^{3} \ln \alpha_{\text {glass-water }}$ for the mafic glasses, prior to the magmatic correction, it becomes $+19 \%$ o $( \pm 32$

$518 \%$; $1 \square \square$. d.), which is likely due to the prevalence of magmatic water in the mafic glasses with

519 heavier $\delta \mathrm{D}$ values, signifying the importance of the magmatic correction. Similar to the felsic

520 glasses, we compare fractionations between regions of cold and wet versus hot and dry climates.

521 For the cold and wet region of Kamchatka, the average $10^{3} \ln \alpha_{\text {glass-water }}$ is $-19 \%$ ( $\pm 19 \%$; 
$5221 \square \square$.d.), and for the hot and dry region of Tanzania (MAT of $\sim 23{ }^{\circ} \mathrm{C}$ and annual precipitation of

$523 \sim 600 \mathrm{~mm})$ the average $10^{3} \ln \alpha_{\text {glass-water }}$ is $-60 \%$ ( $\pm 11 \%$; $1 \square \square$. d. $)$. This indicates a similar trend

524 of greater fractionations for hot and dry climates in the mafic glasses. Also similar to the felsic

525 trend, we have minimal samples to base this trend on, and therefore, it is uncertain if this trend is

526 significant.

527

$528 \quad 4.3$ Hydration of basalt versus rhyolite

529 There is a clear distinction between the hydration rates of basalt and rhyolite glass (Fig.

530 8). This difference is likely due either to the difference in diffusion rates of water into basaltic

531 and rhyolitic glass, differences in vesicularities, or both. Due to the long time (1000s of years)

532 needed for room temperature hydration, there are no experiments on rates of room temperature

533 hydration of basalt or rhyolite tephra. Therefore, experimental data for rhyolite and basalt

534 diffusivities only go to $400{ }^{\circ} \mathrm{C}$ (e.g. Zhang and Behrens, 2000).

535 As we documented above (Fig. 4, Table 4), rhyolitic tephra has a significantly higher

536 vesicle number density $\left(736 \mathrm{~mm}^{-2}\right)$ relative to basalts and andesites $\left(27-161 \mathrm{~mm}^{-2}\right)$. The

537 important implication of this difference in bubble number densities is that surface area increases

538 with an increase in bubble number density, which we examine further below.

539

540 4.3.1 Hydration rates of coeval tephra across differing climates

541 We compare the $\mathrm{H}_{2} \mathrm{O}_{t}$ of tephra of similar age and relative vesicularities across different

542 climatic regions and do not observe consistent differences in hydration rates of felsic or mafic

543 tephra (Fig. 8). In terms of the felsic samples, the Chilean glasses were hydrated in the warmest

544 and wettest climate and we compare these tephra to the cooler climates of Kamchatka and 
545 Oregon (United States). We compare the youngest Chilean glass (CLD064B; 3 ka) with a

546 similarly aged Kamchatkan glass from Opala (98-33/2) that has similar vesicularity (Table 3)

547 and find similar water concentrations. However, when we compare an older Chilean glass

548 (CLD155A) with a similar vesicularity to the $4.6 \mathrm{ka}$ Optr glass (98KAM2.3), we do not find

549 similar water concentrations ( $3.2 \mathrm{wt} . \% \mathrm{H}_{2} \mathrm{O}_{\mathrm{t}}$ relative to $2.1 \mathrm{wt} . \% \mathrm{H}_{2} \mathrm{O}_{\mathrm{t}}$ ). Based on the random

550 differences in water concentrations between the few tephra of the warm and wet Chilean climate

551 that we can compare to specific Kamchatkan samples, we cannot conclude that there are any

552 consistent differences in rates of hydration for felsic glasses of differing climates (i.e. cold versus

553 warm). However, we only have a few warm samples to work with, and therefor more research

554 should be done to clarify these results.

555 We can utilize a similar comparison of the mafic Tanzanian glasses, which were hydrated

556 in a warmer and dryer climate to the cold and wet climate of the Kamchatkan glasses (Fig. 8a;

557 Table 3). However, specific age and vesicularity comparisons are difficult, due to the few

558 samples we have from warm and dry climates. The 2.0 ka Rungwe tephra (KF155D) is bracketed

559 by the 1.0 and 2.8 ka Shiveluch glasses (96025/4 and 97051/2), which both have lower relative

560 vesicularities and lower water concentrations. We compare the older (4.0 ka) Rungwe glass

561 (KF149B) to the 2.8 ka Shiveluch tephra and the 7.5 ka Kizimen tephra (80013/4), which have

562 lower relative vesicularities, and lower and higher water concentrations, respectively. Again,

563 based on the random differences in total water concentrations for both the mafic and felsic

564 glasses that we see here, there does not appear to be any consistent difference in hydration rates

565 for glasses hydrated in different climatic regions. However, we don't have very many dry climate

566 samples to work with, and more research should be done to clarify these results. 


\subsection{Simplified model for diffusion of water through vesicular glass}

A longstanding experimental challenge is the measurement of the diffusivity of water in

570 volcanic glass at ambient temperature. Because the rate of diffusion is so slow, and therefore

571 difficult to investigate with experiments, one approach is to measure the thickness of hydration

572 rinds on obsidians of known age (e.g. Anovitz et al., 2004). In this section, we develop a

573 complementary approach in which we model the hydration versus time data presented in Figure

5748 to obtain an order-of-magnitude estimate of the low-temperature diffusivity of $\mathrm{H}_{2} \mathrm{O}_{\mathrm{t}}$ in both

575 vesicular rhyolite and basaltic scoria.

576 The key observations we focus our attention on are: 1) the $\mathrm{H}_{2} \mathrm{O}_{\mathrm{t}}$ in rhyolitic pumices

577 increases between 0 and $2 \mathrm{ka} ; 2$ ) most of the basaltic scoria are considerably less hydrated than

578 their rhyolitic counterparts; 3 ) there is no systematic relationship between age and $\mathrm{H}_{2} \mathrm{O}_{t}$ in

579 rhyolitic or basaltic tephra older than $2 \mathrm{ka}$; and 4) basaltic scoria older than $1.5 \mathrm{ka}$ are more

580 hydrated than modern basalts. It is important to note at the outset that we do not have

581 independent constraints on the solubility of water in basalt and rhyolite at low temperature, and

582 we make the assumption that the solubility of water in mafic and felsic glasses is similar.

583 We model the diffusive influx of water into a glass wall between two bubbles in 1D to

584 estimate the rate at which the glass wall becomes hydrated as a function of the diffusivity of

585 water and average vesicle wall thickness (Fig. 11a-b). An alternative way to think of this is that

586 we are representing a 1-10 $\mathrm{mg}$ aliquot of ash as a square slab with a thickness that is represented

587 by an average bubble wall thickness. At an equivalent mass, thinner-walled tephra clasts will

588 have a greater surface area. In the model, the glass wall initially has $0.1 \mathrm{wt} . \%$ water and we

589 assume a $5 \mathrm{wt}$ \% fixed concentration of water at the boundaries, which is near our highest water

590 content after 10,000 years. The fixed concentration boundary conditions imply that the clast as a 
591 whole is highly permeable such that environmental water can penetrate into most of the pores.

592 Although the water concentration of $5 \mathrm{wt} . \%$ at the boundaries is fixed, the diffusivity within the

593 model varies with time as the water concentration changes.

594 The two parameters in the model that determine the rate of hydration versus time are (1)

595 the length that water has to travel to hydrate the glass (average bubble wall thickness) and (2) the

596 diffusivity of water. Because hydration rinds are observed to have relatively sharp boundaries

597 due to the water-concentration dependence of diffusivity (Eq. 1 and surrounding discussion),

598 similar to what is seen in studies involving glass corrosion (e.g. Gin et al., 2013; Steefel et al.,

599 2015), we adopt the formulation for the water concentration dependent rhyolite diffusion

600 equation from Zhang and Behrens (2000):

$$
\begin{aligned}
& D_{\mathrm{H}_{2} \mathrm{O}_{t}} \\
& =X \exp (m)\{1 \\
& \left.+\exp \left[56+m+X\left(-34.1+\frac{44,620}{T}+\frac{57.3 P}{T}\right)-\sqrt{X}\left(0.091+\frac{4.77 \times 10^{6}}{T^{2}}\right)\right]\right\}
\end{aligned}
$$

602 where $D$ is a water concentration diffusion coefficient in $\mu \mathrm{m}^{2} / \mathrm{s}$ for molecular water, $m=-20.79$ -

$6035030 / T-1.4 P / T, T$ is the temperature in Kelvin, $P$ is the pressure in MPa, and $X$ is the mole

604 fraction of $\mathrm{H}_{2} \mathrm{O}_{t}$ on a single oxygen basis. This equation, however, is based on experimental and

605 literature data at temperatures $>400{ }^{\circ} \mathrm{C}$, and we therefore only utilize it for its dependence on

606 water concentrations at these higher temperatures, while making the assumption that the

607 functional form is still the same at much lower temperatures. As water diffusivity in glass

608 strongly increases with water concentration (Zhang and Behrens, 2000), we first use the slowest

609 water diffusivity at $0.1 \mathrm{wt} . \%$ as the rate-limiting factor for water diffusion. Furthermore, since 
610 diffusion is much slower at $25^{\circ} \mathrm{C}$, we scale the diffusivity by a constant prefactor, which turns

611 out to be between $10^{-8}$ and $10^{-10}$, in order to match the trend of increasing $\mathrm{H}_{2} \mathrm{O}_{\mathrm{t}}$ with age from our

612 data. The constant prefactor is the only free parameter, as we use average bubble wall

613 thicknesses inferred from the imaged tephra clasts in Figure 4 and Table 4.

614 Figure 11c-d shows an example diffusion simulation for the 7.6 Kurile Lake rhyolite.

615 The initial diffusivity (at 0.1 wt. $\% \mathrm{H}_{2} \mathrm{O}_{\mathrm{t}}$ ) required to yield an average water concentration of 2.3

616 wt. $\%$ after $7.6 \mathrm{ka}$ is on the order of $10^{-4} \mu \mathrm{m}^{2} /$ year. Hereafter, we report diffusivities at $0.1 \mathrm{wt} . \%$

617 water because this is the value that governs the length scale of diffusion according to Eq. 1. The

618 value of $10^{-4} \mathrm{\mu m}^{2} /$ year for the Kurile Lake rhyolite is somewhat sensitive to the solubility of

619 water, or the assumed concentration of water at the boundary. For example, assuming a boundary

620 concentration of $3 \mathrm{wt} . \%$ increases the diffusivity needed to match $2.3 \mathrm{wt} . \%$ at 7600 years by one

621 order of magnitude to $10^{-3} \mu \mathrm{m}^{2} /$ year.

622 We applied the same approach to modeling each of the six imaged tephra clasts for which

623 we have SEM images of bubble wall thickness. The youngest Klyuchveskoy basaltic andesite

624 (KLV5-1, $0.05 \mathrm{ka}$ ) was not included in this analysis, since the water in this clast is likely all

625 magmatic water, based on its young age, high $\delta \mathrm{D}$, and low water concentration. All diffusivities

626 for these samples are within the same order of magnitude $\left(10^{-4} \mu \mathrm{m}^{2} / \mathrm{year}\right.$; results not shown).

627 Lengths that we determine from our model produce similar rates of secondary hydration (1-10

$628 \mu \mathrm{m} / 1000$ years) as were documented by Friedman et al. (1966). Figure 11e shows the length of

629 hydration taken from the modeled 1D diffusion profile versus age for each of the five samples.

630 Also shown is the temperature-dependence of the rate of hydration as determined from several

631 different studies, and the results are generally consistent except for the discrepancy between 75

632 and $100{ }^{\circ} \mathrm{C}$. The results from our five samples compare favorably to samples that were naturally 
633 hydrated at $15-20^{\circ} \mathrm{C}$. The slightly slower rate of hydration for our tephra samples from

634 Kamchatka could be attributed to a number of factors, but it is noteworthy that the mean annual

635 temperature of Kamchatka is about $5{ }^{\circ} \mathrm{C}$, which could theoretically cause slightly slower

636 hydration than at $15-20{ }^{\circ} \mathrm{C}$.

637 Figure 12 shows the tradeoff between diffusivity and vesicularity (or average bubble wall

638 thickness) for the entire sample set, with the exception of three mafic samples with $>2 \mathrm{wt} . \%$

639 water. For the felsic tephra, we vary the bubble wall thicknesses from 10-20 $\mu \mathrm{m}$, based on the

640 Kurile Lake rhyolite. For the mafic tephra, we vary the bubble wall thicknesses from 60-70 $\mu \mathrm{m}$,

641 based on the average bubble wall thicknesses for the imaged mafic tephra (Fig. 12). Each panel

642 corresponds to a specified bubble wall thickness, and the curves that bracket the data represent

643 different diffusivities. Based on this comparison, we find that diffusivities for both felsic and

644 mafic glass range between $10^{-3}$ and $10^{-5} \mu^{2} /$ year, with the upper bounds for both the felsic and

645 mafic glass having diffusivities $\sim 10^{-3} \mu \mathrm{m}^{2} /$ year, the lower bound of the felsic glasses having

646 diffusivities of $\sim 10^{-4} \mu^{2} / y e a r$, and the lower bound of the mafic glasses having diffusivities

$647 \sim 10^{-5} \mu \mathrm{m}^{2} /$ year (Figure 12).

648 In Figure 12, the symbols represent geographic setting. In Figure 13, we use symbols

649 corresponding to the relative vesicularity. The first thing to note is that the highest water content

650 samples have high vesicularity, whereas the lowest water content samples span the full range

651 from low to high vesicularity. This is true for both mafic and felsic samples. Note that we plot

652 results for a larger range of bubble wall thicknesses than used in Figure 12, which is necessary to

653 fit the highest water content mafic samples. When comparing diffusivities, we still see no

654 significant difference between mafic versus felsic glasses at low temperatures. Therefore, we

655 conclude that rhyolite tephra becomes hydrated more rapidly on average than basaltic tephra 
656 because of higher reactive surface areas arising from higher vesicularity and smaller average

657 bubble wall thickness. Although the vast majority of the felsic tephra hydrate faster than the

658 mafic tephra in this study, there are three mafic samples (the 2.0 and 4.0 ka Rungwe glass and

659 the 7.5 ka Kizimen glass) that became hydrated at a similar rate to some of the felsic tephra.

660 These tephra all have higher vesicularities than most other mafic tephra, which provides a larger

661 surface area for hydration (Table 3). Rust and Cashman (2011) compiled the relative bubble

662 number densities of basalt and rhyolite tephra and showed that rhyolite tephra have consistently

663 higher bubble number densities (and therefore surface areas), regardless of the mass eruption

664 rate, than mafic tephra. Their compilation also showed that mafic tephra have bubble number

665 densities that increase with increasing mass eruption rates, which correlates with our results of

666 only a few of the mafic tephra being hydrated at similar rates to the felsic tephra.

667 Furthermore, when plotted versus age, there is a range of hydration rates for basaltic

668 glasses, with the Klyuchevskoy basalts being hydrated at the slowest rates (Fig. 8). There are two

669 potential explanations for this difference: (1) the lower explosivity of the Klyuchevskoy

670 eruptions translates to fewer vesicles, and therefore, thicker bubble walls (Table 4; Figs. 4-6).

671 This would cause water to take longer to penetrate through all the glass; and/or (2) the presence

672 of microlites causes water to diffuse through longer effective pathways, and thus slowly through

673 the pyroclast. Both thicker bubble walls and abundance of microlites have been documented in

674 the Klyuchevskoy tephra, which explains the unusually slow hydration rate of the Klyuchevskoy 675 tephra.

676

677 4.4.1 Modeling D/H diffusion during secondary hydration 
To further understand the $\delta \mathrm{D}$ trends of secondary hydration, we created a similar code to

679 incorporate the $\mathrm{D} / \mathrm{H}$ trends during diffusion of water into volcanic glass at ambient temperature 680 for the 7.6 ka Kurile Lake rhyolite (97KAM29AL) from Kamchatka, Russia. We use the same

681 model set up from the water-based diffusion model discussed above, except the starting

682 conditions are now based on the relative deuterium concentrations from the $\delta \mathrm{D}$ of our magmatic 683 correction $\left(-83 \%\right.$ ) at $0.1 \mathrm{wt} . \% \mathrm{H}_{2} \mathrm{O}_{\mathrm{t}}$, and the boundary conditions are based on the current local $684 \delta$ D of precipitation (-107 \% ) from Bowen and Revenaugh (2003) and Bowen (2015), while 685 including the fractionation between water in glass and meteoric water from Friedman et al. 686 (1993a) for a $\delta \mathrm{D}$ boundary condition of $-137 \%$. For the purpose of this model, we assumed that 687 water addition and $\mathrm{D} / \mathrm{H}$ exchange coincide. We compare this model to the $\delta \mathrm{D}$ values of our 688 samples that have been magmatic corrected (Fig. 14), and note that our model produces similar 689 results to the schematic curve from Figure 2, and the magma corrected $\delta \mathrm{D}$ value of our $7.6 \mathrm{ka}$ 690 Kurile Lake rhyolite. This correlation illustrates both the appropriateness of our model, and the 691 ability to obtain similar $\delta \mathrm{D}$ values for water extracted from volcanic glass (following a magmatic 692 correction) and the local $\delta \mathrm{D}$ of precipitation.

\section{5. CONCLUSIONS}

695 1) We demonstrate the characteristics of the hydrogen isotope variations of secondary 696 hydration of volcanic glass, which illustrates a decrease in the $\delta \mathrm{D}$ value with increasing water in 697 nearly all environments except equatorial.

698 2) We propose a correction for pre-existing undegassed magmatic water when

699 determining paleoenvironments, where younger tephra from the same section can be used to 700 constrain the $\delta \mathrm{D}$ and concentration of residual magmatic water of older tephra clasts. If younger 
701 tephra from the same section are not available, our average $\delta \mathrm{D}$ of $-83 \%$ and $\mathrm{H}_{2} \mathrm{O}_{\mathrm{t}}$ of $0.32 \mathrm{wt} . \%$

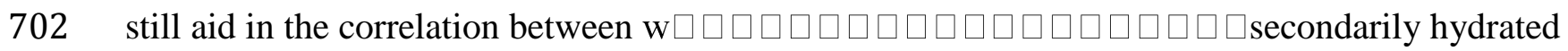

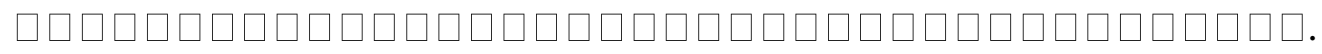

3) We show that $\delta \mathrm{D}$ values of water in felsic volcanic glass $(\leq \sim 10,000$ years $)$, when

705 compared to present meteoric water, yield uncertainties of $\pm 4 \%$ from the current $\delta \mathrm{D}$ of meteoric 706 water after a magmatic correction.

707 4) Following our magmatic correction, we calculate $10^{3} \ln \alpha_{\text {glass-water }}$ values that average -

$70833 \%$ for hydrated felsic glasses, which is similar to the $10^{3} \ln \alpha_{\text {glass-water }}$ value determined by

709 Friedman et al. (1993a). We also identify a smaller average $10^{3} \ln \alpha_{\text {glass-water }}$ for all mafic glasses

710 across differing climates of $-23 \%$.

711 5) We demonstrate that felsic glass typically becomes mostly hydrated after $\sim 1500$ years

712 with 1.5-3.5 wt. $\% \mathrm{H}_{2} \mathrm{O}_{\mathrm{t}}$, but mafic glass is typically still not hydrated beyond $1.5 \mathrm{wt} . \% \mathrm{H}_{2} \mathrm{O}_{\mathrm{t}}$

713 even after 7000 years.

714 6) When corrected for greater bubble number density of rhyolites, we empirically

715 estimate, using our tephrachronological sample set, that the diffusivity of water into felsic glass

716 is within the same order of magnitude as mafic glass.

717 7) We estimate the initial (at $0.1 \mathrm{wt} . \% \mathrm{H}_{2} \mathrm{O}_{\mathrm{t}}$ ) diffusion coefficient for water in felsic and

718 mafic glass at ambient temperatures and pressures to be between $10^{-3}$ and $10^{-4} \mu \mathrm{m}^{2} / \mathrm{year}$. This

719 equates to a constant prefactor for the Zhang and Behrens (2000) rhyolite diffusion equation for

720 temperatures above $400^{\circ} \mathrm{C}$ that ranges between $10^{-8}$ and $10^{-10}$, and provides similar rates of

721 secondary hydration (1-10 $\mu \mathrm{m} / 1000$ years) determined earlier by Friedman et al. (1966).

\section{ACKNOWLEDGMENTS}


725 Mazama ash and pumice around Oregon. We also thank Heather Wright for recently erupted

726 samples from Indonesia, Caroline Gordon for Mt. Mazama samples from the Ochoco National

727 Forest, and Karen Fontijn for samples from Chile and Tanzania. We would like to express our

728 gratitude to Vera Ponomareva for fieldwork assistance and sharing samples from Kamchatka that

729 were utilized in this research. We are also indebted to Gary Nolan and Jim Palandri for

730 discussions and assistance with TCEA analyses. We would also like to thank Julie Chouinard for

731 assistance with SEM imaging. A.N.S. owes a very large thank you to Dana Drew for assistance

732 with fieldwork and sample collection, Danielle McKay for assistance with tephra sampling in

733 central Oregon, and Randy Krogstad for assistance with the Matlab code. We also thank Carl

734 Steefel and an anonymous reviewer for their constructive reviews and Marc Norman and Carl

735 Steefel for editorial handling. This work was supported by the NSF [EAR/CAREER-844772], a

736 Kleinman grant, and a grant from the Evolving Earth Foundation.

\section{REFERENCES}

739

740

741

742

743

744

745

746

747

748

749

750

751

752

753
Anovitz L. M., Elam J. M., Riciputi L. R. and Cole D. R. (2004) Isothermal time-series determination of the rate of diffusion of water in Pachuca obsidian. Archaeometry 46, 301-326.

Anovitz L. M., Cole D. R. and Fayek M. (2008) Mechanisms of rhyolitic glass hydration below the glass transition. Am. Mineral. 93, 1166-1178.

Anovitz L. M., Cole D. R. and Riciputi L. R. (2009) Low-temperature isotopic exchange in obsidian: Implications for diffusive mechanisms. Geochimica et Cosmochimica Acta 73(13), 3795-3806.

Auer S., Bindeman I., Wallace P., Ponomareva V., and Portnyagin M. (2009) The origin of hydrous, high- $\delta{ }^{18} \mathrm{O}$ voluminous volcanism: diverse oxygen isotope values and high magmatic water contents within the volcanic reord of Klyuchevskoy volcano, Kamchatka, Russia. Contrib. Mineral. Petrol. 157, 209-230.

Bindeman I. N., Kamenetsky V., Palandri J. and Vennemann T. (2012) Hydrogen and oxygen isotope behavior during variable degrees of upper mantle melting: example from the basaltic glasses from Macquarie Island. Chemical Geology 310-311, 126-136. 
754

755

756

757

758

759

760

761

762

763

764

765

766

767

768

769

770

771

772

773

774

775

776

777

778

779

780

781

782

783

784

785

786

787

788

789

790

791

792

793

794

795

796

797

798

799

Bowen G. J. and Revenaugh J. (2003) Interpolating the isotopic composition of modern meteoric precipitation. Water Resources Research 39(10), 1299.

Bowen G.J. (2015) The Online Isotopes in Precipitation Calculator, version 2.2. http://www.waterisotopes.org.

Braitseva O. A., Ponomareva V. V., Sulerzhitsky L. D., Melekestsev I. V. and Bailey J. (1997) Holocene key-marker tephra layers in Kamchatka, Russia. Quaternary Research 47, 125139.

Cailleteau C., Angeli F., Devreux F., Gin S., Jestin J., Jollivet P. and Spalla O. (2008) Insight into silicate-glass corrosion mechanisms. Nature Materials 7, 978-983.

Canavan R. R., Carrapa B., Clementz M. T., Quade J., DeCelles P. G. and Schenbohm L. M. (2014) Early Cenozoic uplift of the Puna Plateau, Central Andes, based on stable isotope paleoaltimetry of hydrated volcanic glass. Geology 42, 447-450.

Cassel E. J., Graham S. A., Chamberlain C. P. and Henry C. D. (2012) Early Cenozoic topography, morphology, and tectonics of the northern Sierra Nevada and western Basin and Range. Geosphere 8, 229-249.

Cassel E. J., Breecker D. O., Henry C. D., Larson T. E. and Stockli D. F. (2014) Profile of a paleo-orogen: High topography across the present-day Basin and Range from 40 to 23 Ma. Geology 42(11), 1007-1010.

Castro J. M., Bindeman I. N., Tuffen H. and Schipper C. I. (2014) Explosive origin of silcic lava: Textural and $\delta \mathrm{D}-\mathrm{H}_{2} \mathrm{O}$ evidence for pyroclastic degassing during rhyolite effusion. Earth and Planetary Science Letters 405, 52-61.

Cerling T. E., Brown F. H. and Bowman J. R. (1985) Low-temperature alteration of volcanic glass: Hydration, Na, K, ${ }^{18} \mathrm{O}$, and Ar mobility. Chem. Geol. 52, 281-293.

Crovisier J., Advocat T. and Dussossoy J. (2003) Nature and role of natural alteration gels formed on the surface of ancient volcanic glasses (Natural analogs of waste containment glasses). Journal of Nuclear Materials 321, 91-109.

DeGroat-Nelson P. J., Cameron B. I., Fink J. H. and Holloway J. R. (2001) Hydrogen isotope analysis of rehydrated siclic lavas: Implications for eruption mechanisms. Earth Planet. Sci. Lett. 185, 331-341.

Dettinger M. P. and Quade J. (2015) Testing the analytical protocols and calibration of volcanic glass for the reconstruction of hydrogen isotopes in paleoprecipitation. In Geodynamics of a Cordilleran Orogenic System: The Central Andes of Argentina and Northern Chile (eds. P.G. DeCelles, M.N. Ducea, B. Carrapa, P.A. Kapp), Geological Society of America, vol. 212, pp. 261-276.

Dobson P. F., Epstein S. and Stolper E. M. (1989) Hydrogen isotope fractionation between coexisting vapor and silicate glasses and melts at low pressure. Geochimica et Cosmochimica Acta 53, 2723-2730.

Eerkens J. W., Vaughn K. J., Carpenter T. R., Conlee C. A., Grados M. L. and Schreiber K. (2008) Obsidian hydration dating on the south coast of Peru. Journal of Archaeological Science 35, 2231-2239.

Ferrand K., Abdelouas A. and Grambow B. (2006) Water diffusion in the simulated French nuclear waste glass SON 68 contacting silica rich solutions: Experimental and modeling. Journal of Nuclear Materials 355, 54-67.

Fontijn K., Ernst G. G. J., Elburg M. A., Williamson D., Abdallah E. Kwelwa S., Mbede E. and Jacobs P. (2010) Holocene explosive eruptions in the Rungwe Volcanic Province, Tanzania. Journal of Volcanology and Geothermal Research 196, 91-110. 

Roa H. (2014) Late Quaternary tephrostratigraphy of southern Chile and Argentina. Quaternary Science Reviews 89, 70-84.

Friedman I., Smith R. L. and Long W. D. (1966) Hydration of natural glass and formation of perlite. Geological Society of America Bulletin 77, 323-328.

Friedman I., Gleason J., Sheppard R. A., Gude A. J. (1993a) Deuterium fractionation as water diffuses into silicic volcanic ash. Geophysical Monograph 78, 321-323.

Friedman I., Gleason J. and Warden A. (1993b) Ancient climate from deuterium content of water in volcanic glass. Geophysical Monograph 78, 309-319.

Giachetti T. and Gonnermann H. M. (2013) Water in volcanic pyroclast: Rehydration or incomplete degassing?. Earth and Planetary Science Letters 369-370, 317-332.

Giachetti T., Gonnermann H. M., Gardner J. E., Shea T. and Gouldstone, A. (2015) Discriminating secondary from magmatic water in rhyolitic matrix-glass of volcanic pyroclasts using thermogravimetric analysis. Geochimica et Cosmochimica Acta 148, $457-476$.

Gin S., Ryan J. V., Schreiber D. K., Neeway J. and Cabié M. (2013) Contribution of atom-probe tomography to a better understanding of glass alteration mechanisms: Application to a nuclear glass specimen altered 25 years in a granitic environment. Chemical Geology 349-350, 99-109.

Henderson A. K., Nelson D. M., Hu F. S., Huang Y., Shuman B. N. and Williams J. W. (2010) Holocene precipitation seasonality captured by a dual hydrogen and oxygen isotope approach at Steel Lake, Minnesota. Earth and Planetary Science Letters 300, 205-214.

Ihinger P. D., Zhang Y. and Stolper E. M. (1999) The speciation of dissolved water in rhyolitic melt. Geochimica et Cosmochimica Acta 63, 3567-3578.

Jezek P. A. and Noble D. C. (1978) Natural hydration and ion exchange of obsidian: An electron microprobe study. American Mineralogist 63, 266-273.

Kyle P. R., Ponomareva V. V. and Chluep R. R. (2011) Geochemical characterization of marker tephra layers from major Holocene eruptions, Kamchatka Peninsula, Russia. International Geology Review 53, 1059-1097.

Mazer J. J., Stevenson C. M., Ebert W. L. and Bates J. K. (1991) The experimental hydration of obsidian as a function of relative humidity and temperature. American Antiquity 56, 504513.

Mulch A., Sarna-Wojcicki A. M., Perkins M. E. and Chamberlain C. P. (2007) A Miocene to Pleistocene climate and elevation record of the Sierra Nevada (California). Proceedings of the National Academy of Sciences 105(19), 6819-6824.

Newman S., Stolper E. M. and Epstein S. (1986) Measurement of water in rhyolitic glasses: Calibration of an infrared spectroscopic technique. American Mineralogist 71, 15271541.

Newman S., Epstein S. and Stolper E. (1988) Water, carbon dioxide, and hydrogen isotopes in glasses from the ca. 1340 A.D. eruption of the Mono Craters, California: Constraints on degassing phenomena and initial volatile content. Journal of Volcanology and Geothermal Research 35(1-2), 75-96.

Nolan G. S. and Bindeman I. N. (2013) Experimental investigation of rates and mechanisms of isotope exchange $(\mathrm{O}, \mathrm{H})$ between volcanic ash and isotopically-labeled water. Geochimica et Cosmochimica Acta 111, 5-27. 
845

846

847

848

849

850

851

852

853

854

855

856

857

858

859

860

861

862

863

864

865

866

867

868

869

870

871

872

873

874

875

876

877

878

879

880

881

882

883

884

885

886

887

888

889

Parruzot B., Jollivet P., Rébiscoul D. and Gin S. (2015) Long-term alteration of basaltic glass: Mechanisms and rates. Geochimica et Cosmochimica Acta 154, 28-48.

Ponomareva V., Kyle P. R., Melekestsev I. V., Rinkleff P. G., Dirksen O. V., Sulerzhitksy L. D., Zaretskaia N. E. and Rourke R. (2004) The $7600\left({ }^{14} \mathrm{C}\right)$ year BP Kurile Lake calderaforming eruption, Kamchatka, Russia: stratigraphy and field relationships. Journal of Volcanology and Geothermal Research 136, 199-222.

Ponomareva V., Melekestev I., Braitseva O., Churikova T., Pevzner M. and Sulerzhitsky L. (2007) Late Pleistocene-Holocene volcanism on the Kamchatka Peninsula, Northwest Pacific Region. In Volcanism and Subduction: The Kamchatka Region (eds. J. Eichelberger, E. Gordeev, M. Kasahara, P. Izbekov, J. Lees), American Geophysical Union, Geophysical Monograph 172, 165-198.

Ponomareva V., Portnyagin M., Derkachev A., Pendea I. F., Bourgeois J., Reimer P. J., GarbeSchönberg D., Krasheninnikov S. and Nürnberg D. (2013) Early Holocene M 6 explosive eruption from Plosky volcanic massif (Kamchatka) and its tephra as a link between terrestrial and marine paleoenvironmental records. International Journal of Earth Sciences 102, 1673-1699.

Princen H. (1979) Highly concentrated emulsions. I. Cylindrical systems. Journal of Colloid and Interface Science 71, 55-66.

Proussevitch A. A., Sahagian D. L. and Anderson A. T. (1993) Dynamics of diffusive bubble growth in magmas: isothermal case. Journal of Geophysical Research 98, 22283-22307.

Qi H., Gröning M., Coplen T. B., Buck B., Mroczkowski S. J., Brand W. A., Geilmann H. and Gehre M. (2010) Novel silver-tubing method for quantitative introduction of water into high-temperature conversion systems for stable hydrogen and oxygen isotopic measurements. Rapid Communications in Mass Spectrometry 24, 1821-1827.

Qi H., Coplen T. B., Olack G. A. and Vennemann T. W. (2014) Caution on the use of NBS 30 biotite for hydrogen-isotope measurements with on-line high-temperature conversion systems. Rapid Communications in Mass Spectrometry 28, 1987-1994.

Rébiscoul D., Rieutord F., Né F., Frugier P., Cubitt R. and Gin S. (2007) Water penetration mechanisms in nuclear glasses by X-ray and neutron reflectometry. Journal of NonCrystalline Solids 353, 2221-2230.

Riciputi L. R., Elam J. M., Anovitz L. M. and Cole D. R. (2002) Obsidian diffusion dating by Secondary Ion Mass Spectrometry: A test using results from Mound 65, Chalco, Mexico. Journal of Archaeological Science 29(10), 1055-1075.

Ross C. S. and Smith R. L. (1955) Water and other volatiles in volcanic glasses. American Mineralogist 40, 1071-1089.

Rust A. C. and Cashman K. V. (2011) Permeability controls on expansion and size distributions of pyroclasts. J. Geophys. Res. 116, 1-17.

Sarna-Wojcicki A. M. and Davis J. O. (1991) Quaternary tephrochronology. In Quaternary nonglacial geology-conterminous U.S. (eds. R. B. Morrison), Geological Society of America, Geology of North America K2, 93-116.

Shane P. and Ingraham N. (2002) $\delta \mathrm{D}$ values of hydrated volcanic glass: A potential record of ancient meteoric water and climate in New Zealand. New Zealand Journal of Geology \& Geophysics 45(4), 453-459.

Silver L. A., Ihinger P. D. and Stolper E. (1990) The influence of bulk composition on the speciation of water in silicate glasses. Contrib. Mineral. Petrol. 104, 142-162. 
Steefel C. I., Beckingham L. E. and Landrot G. (2015) Micro-continuum approaches for modeling pore-scale geochemical processes. Reviews in Mineralogy \& Geochemistry 80, 217-246.

Stroncik N. A. and Schmincke H. (2002) Palagonite - a review. International Journal of Earth Sciences 91, 680-697.

Tuffen H., Owen J. and Denton J. S. (2010) Magma degassing during subglacial eruptions and its use to reconstruct palaeo-ice thicknesses. Earth Sci. Rev. 99, 1-18.

Valle N., Verney-Carron A., Sterpenich J., Libourel G., Deloule E. and Jollivet P. (2010) Elemental and isotopic $\left({ }^{29} \mathrm{Si}\right.$ and $\left.{ }^{18} \mathrm{O}\right)$ tracing of glass alteration mechanisms. Geochimica et Cosmochimica Acta 74, 3412-3431.

Zhang Y. (1999) $\mathrm{H}_{2} \mathrm{O}$ in rhyolitic glasses and melts: Measurement, speciation, solubility, and diffusion. Reviews in Geophysics 37, 493-516.

Zhang Y. and Behrens H. (2000) $\mathrm{H}_{2} \mathrm{O}$ diffusion in rhyolitic melts and glasses. Chemical Geology 169, 243-262.

\section{FIGURE CAPTIONS}

Figure 1. Sample locations along with local $\delta \mathrm{D}$ of precipitation range in \%o plotted on a world map with an overlay of $\delta \mathrm{D}$ values (\%) of current precipitation (Bowen and Revenaugh, 2003; Bowen, 2015). The map was created using GeoMapApp as the underlying base map (the Global Multi-Resolution Topography (GMRT) synthesis). GPS coordinates and local $\delta \mathrm{D}(\%)$ of precipitation values for sample locations can be found in Table 1 .

Figure 2. $\delta \mathrm{D}_{\text {glass }}$ in relation to the total concentration of water extracted from the glass (error bars illustrate \pm 1 s.d. $\square$. Two separate trends are shown: 1) The relationship between the $\delta \mathrm{D}(\%)$ and $\mathrm{H}_{2} \mathrm{O}_{\mathrm{t}}$ (wt.\%) of volcanic degassing from Newman et al. (1988) and Castro et al. (2014) showing a decrease in $\delta \mathrm{D}(\%)$ with a decrease in total water concentration in the glass. The volcanic degassing trend illustrates the wide range in $\delta \mathrm{D}$ values for magmatic waters worldwide, with a trend towards heavier $\delta \mathrm{D}$ values at higher water concentrations; and 2) The relationship between the $\delta \mathrm{D}(\%)$ and $\mathrm{H}_{2} \mathrm{O}_{\mathrm{t}}$ (wt.\%) of secondary hydration, which generally shows a decrease in $\delta \mathrm{D}(\%)$ with an increase in total water concentration in the glass. Although these trends are opposite one another, there is an overlap in $\delta \mathrm{D}(\%)$ values at water concentrations below $\sim 1$ wt. $\% \mathrm{H}_{2} \mathrm{O}_{\mathrm{t}}$ between volcanic degassing and secondary hydration of volcanic glass. Otherwise, values above $\sim 1 \mathrm{wt} . \% \mathrm{H}_{2} \mathrm{O}_{\mathrm{t}}$, below $\sim-70 \% \delta \mathrm{D}$ signify secondary hydration for non-tropical samples, while heavier $\delta \mathrm{D}(\%)$ values signify volcanic degassing and the presence of mostly primary magmatic water. This is based on the typical lower $\delta \mathrm{D}(\%)$ of precipitation in comparison to the $\delta \mathrm{D}(\%)$ of magmatic water. Local $\delta \mathrm{D}$ of precipitation for the locations where our glass samples were collected range between -35 and $-160 \%$ (Fig. 1). The $\pm 2 \% \delta \mathrm{D}$ and \pm $0.2 \mathrm{wt} . \% \mathrm{H}_{2} \mathrm{O}_{\mathrm{t}}$ on each axis illustrate the typical reproducibility of our TCEA.

Figure 3. Relative quantities of $\mathrm{H}_{2} \mathrm{O}_{\mathrm{t}}$ and $\mathrm{OH}^{-}$as modified from Ihinger et al. (1999), illustrating the larger quantities of $\mathrm{OH}^{-}$relative to total $\mathrm{H}_{2} \mathrm{O}_{\text {mol }}$ as temperature increases. We include potential ranges of recently erupted ash, which are from this study. We also include the location of secondarily hydrated Mt. Mazama ash from Nolan and Bindeman (2013), illustrating the low $\mathrm{OH}^{-}$concentration relative to the concentration of $\mathrm{H}_{2} \mathrm{O}_{\text {mol }}$ for low temperature hydration. 
Figure 4. BSE images of tephra used for basalt-andesite-rhyolite texture comparisons. Note the similarities of bubble number densities and bubble wall thicknesses in the Klyuchevskoy basaltic andesites (KLV5 units). The Klyuchevskoy units typically have fewer, yet larger, vesicles. In contrast, the basalt from the Kurile Lake eruption (97KAM29DB) generally has a larger number of smaller vesicles, which is likely due to the greater explosivity of the eruption. The rhyolite sample from the Kurile Lake eruption (97KAM29AL) has the largest number density and smallest bubble wall thicknesses in comparison to any of the basalts or andesites in this study (see Tables 3-4).

Figure 5. Black and white vesicle images of tephra clasts that were created from the BSE images in Fig. 4. These images were used to determine the number, area, and perimeter of the vesicles for each tephra clast in ImageJ (see Fig. 6).

Figure 6. Results from ImageJ analyses of the black and white images of each tephra clast (see Fig. 5) showing the number, area, and perimeter of the vesicles. Each vesicle counted and analyzed by Image $\mathrm{J}$ is outlined in yellow.

Figure 7. Relationship between the amount of primary magmatic water left in the glass and the $\delta \mathrm{D}$ of the total water (secondary and primary) as determined by TCEA, based on Equations (2) and (3). We do not factor in the variations in $\mathrm{OH}^{-}$and $\mathrm{H}_{2} \mathrm{O}_{\text {mol. }}$. For this calculation, we varied the $\delta \mathrm{D}$ of the primary magmatic water with the $\mathrm{H}_{2} \mathrm{O}_{\mathrm{t}}$ wt. $\%$ of the primary magmatic water during degassing based on degassing trends of Newman et al. (1988) and Castro et al. (2014) using the equation:

$$
\delta D_{\text {mag }}=13.8 \ln \left(\mathrm{H}_{2} \mathrm{O}_{t, \mathrm{mag}}\right)-71
$$
where $\delta D_{\text {mag }}$ is the $\delta \mathrm{D}$ of the magmatic water during degassing in \%o, and $\mathrm{H}_{2} \mathrm{O}_{t, m a g}$ is the wt.\% $\mathrm{H}_{2} \mathrm{O}_{\mathrm{t}}$ of the magmatic water. Given the $\delta \mathrm{D}_{\mathrm{t}}$ that is output by the TCEA results, we calculate the offset produced by the residual magmatic water on the actual $\delta \mathrm{D}$ of the secondary water, assuming there is no shift in the $\delta \mathrm{D}$ of the primary magmatic water during secondary hydration. The plot here shows actual $\delta \mathrm{D}_{\text {met }}$ waters if the $\delta \mathrm{D}_{\mathrm{t}}$ value is $-135 \%$ for different fractions of magmatic water (out of 1.0), and provides the necessary shift in $\delta \mathrm{D}$ values needed to obtain the actual $\delta \mathrm{D}_{\text {met }}$ value.

Figure 8. Water concentration (wt.\%) and $\delta \mathrm{D}(\%)$ trends of water in glass with time (error bars illustrate $\pm 1 \square$.d. $\square$. The mean annual temperature (MAT) in ${ }^{\circ} \mathrm{C}$ and average annual precipitation in $\mathrm{mm}$ are listed for each region in the legend. (a) $\mathrm{H}_{2} \mathrm{O}_{\mathrm{t}}$ (wt.\%) trends for mafic and felsic tephra with age. This plot illustrates a distinction between the hydration rate of basaltic tephra (slower) and rhyolitic tephra (faster), where rhyolitic tephra already contains above 1.5 wt. $\% \mathrm{H}_{2} \mathrm{O}_{\mathrm{t}}$ after $\sim 1500$ years. (b) $\delta \mathrm{D}_{\text {glass }}$ trends for mafic and felsic tephra with age. Since the majority of tephra around the world are hydrated with meteoric water with a lower $\delta \mathrm{D}(\%)$ than the residual primary magmatic water (when factoring in the fractionation between water in glass and meteoric water from Friedman et al. (1993a)), the predominant trend shown during secondary hydration is a decrease in the $\delta \mathrm{D}(\%)$ of the water in the glass. This causes felsic (hydrated) tephra to have a lower $\delta \mathrm{D}(\%)$ value after a few thousand years than the majority of the mafic (not as hydrated) tephra. The $\pm 2 \% \delta \mathrm{D}$ and $\pm 0.2 \mathrm{wt} . \% \mathrm{H}_{2} \mathrm{O}_{\mathrm{t}}$ on the y-axes illustrate the typical reproducibility of our TCEA. 
Figure 9. $\delta \mathrm{D}_{\text {glass }}(\%)$ in comparison to local $\delta \mathrm{D}_{\text {met }}(\%)$. The $1: 1$ line compares the $\delta \mathrm{D}(\%)$ of the water extracted from the volcanic glass (our analyses) to the $\delta \mathrm{D}(\%)$ of current local meteoric water based on interpolated data from waterisotopes.org (Bowen and Revenaugh, 2003; Bowen, 2015). The fractionation between water in glass and meteoric water (Friedman et al., 1993a) has already been taken into account. (a) Results when an average magmatic water $\delta \mathrm{D}(\%)$ value is not excluded from the $\delta \mathrm{D}_{\text {glass }}(\%)$ value. Results here show an average offset of $+24 \%$ from current local meteoric waters for all data. (b) Results showing the improved correlation when the average magmatic water $\delta \mathrm{D}(\%)$ value is removed from the $\delta \mathrm{D}_{\text {glass }}(\%)$ value. The average offset for both mafic and felsic glasses following the magmatic water $\delta \mathrm{D}(\%)$ correction is $+4 \%$. Glasses used to create the magmatic correction and glasses with water concentrations less than the magmatic correction are excluded from (b). Published Mt. Mazama data is from Friedman et al. (1993b).

Figure 10. Deviation from the $\delta \mathrm{D}(\%)$ of local meteoric waters in relation to the age of the glass. The black line running through $0 \%$ designates no deviation from the $\delta \mathrm{D}$ of local meteor water (Bowen and Revenaugh, 2003; Bowen, 2015), after taking into account the Friedman et al. (1993a) fractionation between water in glass and meteoric water. (a) Results when an average magmatic water $\delta \mathrm{D}(\%)$ value is not excluded from the $\delta \mathrm{D}_{\text {glass }}$ value. Nearly all $\delta \mathrm{D}$ glass data fall above the correlation line. (b) Results showing the improved correlation when the average magmatic water $\delta \mathrm{D}(\%)$ value is removed from the $\delta \mathrm{D}_{\text {glass }}$ value. The correction causes more data to fall near the correlation line. Glasses used to create the magmatic correction and glasses with water concentrations less than the magmatic correction are excluded from part (b). Published Mt. Mazama data are from Friedman et al. (1993b).

Figure 11. Comparison and explanation of our model results for water concentration dependent diffusion. (a-b) illustration of the hexagonal close-packing assumption that we utilize in our vesicle and glass layout for our model. The difference between (a) and (b) illustrates the typical difference in bubble wall thicknesses between rhyolite (a) and basalt (b) tephra. (c) Example of our model results for 97KAM29AL (7.6 ka Kurile Lake Rhyolite). 97KAM29AL has an average bubble wall thickness of $17 \mu \mathrm{m}$ (shown on the $\mathrm{x}$-axis). At the start of the model run, the entire bubble wall has 0.1 wt. $\% \mathrm{H}_{2} \mathrm{O}_{\mathrm{t}}$, with $5 \mathrm{wt} . \% \mathrm{H}_{2} \mathrm{O}_{\mathrm{t}}$ at the boundaries. As hydration proceeds $(0.5-$ 7.6 ka shown here), the hydration front produces a 'bulldozing effect' that steadily progresses into the center of the bubble wall, as is shown in the 0.5, 2.0, 5.0, and 7.6 ka markings in gray. The length of hydration (L) for each of our tephra samples was calculated by subtracting the average bubble wall thickness (17 $\mu \mathrm{m}$ here) by the distance to the $0.1 \mathrm{wt} . \%$ non-hydrated region of the bubble wall ( $9.6 \mu \mathrm{m}$ after 7,600 years here). (d) To determine the proper distance needed for hydration, the known bubble wall thickness from the SEM images was entered into our model (17 $\mu \mathrm{m}$ for 97KAM29AL), along with the known age (7.6 ka for 97KAM29AL), and the diffusivity constant was adjusted until the known water concentration from the TCEA analyses was obtained ( $2.3 \mathrm{wt} . \%$ here). This is shown here by the trend of increasing water with time to end at 2.3 wt. $\% \mathrm{H}_{2} \mathrm{O}_{\mathrm{t}}$ after 7,600 years. (e) Results show that there is a decrease in hydration rate with a decrease in temperature and that our model results are similar to those for natural rhyolitic glass hydration at 15 and $20^{\circ} \mathrm{C}$. This is shown by our tephra (from Kurile Lake and Klyuchevskoy) having similar lengths of hydration for similarly aged samples at 15 and $20^{\circ} \mathrm{C}$. Given the slightly lower temperature of our Kamchatka samples $\left(\sim 5^{\circ} \mathrm{C}\right.$ mean annual 
1025 temperature), it is reasonable that our samples have a slightly slower hydration rate than the samples at $15-20^{\circ} \mathrm{C}$. We did not determine the hydration distance of KLV5-1 (0.05 ka Klyuchveskoy scoria) based on its young age, and likely negligible secondary hydration. Prior studies are from Friedman et al. $\left(1966 ; 100^{\circ} \mathrm{C}\right)$, Mazer et al. $\left(1991 ; 175^{\circ} \mathrm{C}\right)$, Anovitz et al. $\left(2004 ; 75^{\circ} \mathrm{C}\right)$, Riciputi et al. $\left(2002 ; 20^{\circ} \mathrm{C}\right)$, and Eerkens et al. $\left(2008 ; 15-20^{\circ} \mathrm{C}\right)$. Higher degree temperatures listed in the legend are approximate and based on the average temperature for the study.

Figure 12. Modeling results from our diffusion code for felsic $(a-c)$ and mafic $(d-f)$ glasses in comparison to our data for water concentration versus age (error bars illustrate \pm 1 s.d. $\square$. For the felsic glasses, the bubble wall thickness was varied between 10, 15, and $20 \mu \mathrm{m}$, and the diffusivities were subsequently varied at each of these average bubble wall thicknesses until the trend lines matched our data. For the basalts, the bubble wall thickness was varied between 60, 65 , and $70 \mu \mathrm{m}$. Diffusivities listed in the figure are the initial diffusivity at $0.1 \mathrm{wt} . \% \mathrm{H}_{2} \mathrm{O}_{\mathrm{t}}$.

Figure 13. Modeling results from our diffusion code for felsic (a) and mafic (b) glass against our data for water concentration versus age (error bars illustrate \pm 1 s.d. $\square$. Vesicularities were split into three groups: 1) highly vesicular samples, with relative vesicularities from 7-10;2) moderately vesicular, with a relative vesicularity of 5; and 3) low vesicularity samples, with relative vesicularities from 1-4. Relative vesicularities are listed in Table 3. Given the vesicular nature of the felsic samples, model runs were only conducted at $15 \mu \mathrm{m}$ bubble wall thickness. Based on the wide range of vesicularities for the mafic samples, highly vesicular data were matched to $25 \mu \mathrm{m}$ bubble walls, moderately vesicular data were matched to $50 \mu \mathrm{m}$ bubble walls, and low vesicularity data were matched to $75 \mu \mathrm{m}$ bubble walls. Results here show similar orders of magnitude diffusion for mafic and felsic samples, when relative vesicularities are accounted for.

1051

Figure 14. Modeling results from our $\delta \mathrm{D}$ diffusion code. The $\delta \mathrm{D}_{\text {glass }}$ values in this figure are magmatic corrected (error bars illustrate \pm 1 s.d. $\square$. Note the lower $\delta \mathrm{D}$ values for the $\delta \mathrm{D}_{\text {glass }}$ data, and the similarity between the model curve and our schematic curve in Figure 2. The model was run up to the $2.3 \mathrm{wt} . \% \mathrm{H}_{2} \mathrm{O}_{\mathrm{t}}$ of the $7.6 \mathrm{ka}$ Kurile Lake rhyolite (97KAM29AL) using the local precipitation annual $\delta \mathrm{D}(\%)$ value from waterisotopes.org (Bowen, 2015; Bowen and Revenaugh, 2003), along with the fractionation between water in glass and meteoric water (Friedman et al., 1993a). The continued dashed line following the solid model curve is a projected continuation of the model trend. The $\pm 2 \% \delta \mathrm{D}$ and $\pm 0.2 \mathrm{wt} . \% \mathrm{H}_{2} \mathrm{O}_{\mathrm{t}}$ on each axis illustrate the typical reproducibility of our TCEA. 
Table 1

Location, age, and local precipitation $\mathrm{D}(\%, \mathrm{VSMOW})$ of glass samples

\begin{tabular}{|c|c|c|c|c|c|c|}
\hline Sample Name & Volcano & Region & Age (ka) & Location $\mathrm{N}$ & Location E & Elevation (m) \\
\hline $99163 / 9$ & Avachinsky & Kamchatka & 3.50 & 53.32 & 158.91 & 826 \\
\hline $99201 / 1$ & Avachinsky & Kamchatka & 7.15 & 53.25 & 159.04 & 369 \\
\hline VF-74-200 & Volcán de Fuego & Guatemala & 0.04 & $14.50^{\mathrm{a}}$ & $-90.90^{a}$ & 2579 \\
\hline VF-74-45 & Volcán de Fuego & Guatemala & 0.04 & $14.50^{\mathrm{a}}$ & $-90.90^{\mathrm{a}}$ & 2579 \\
\hline 808 KAR 4 & Karymsky & Kamchatka & 7.90 & 54.03 & 159.18 & 294 \\
\hline Margomulyo-1p & Kelud & Indonesia & 0.00 & -7.93 & 112.24 & 617 \\
\hline Campling-4p & Kelud & Indonesia & 0.00 & -7.97 & 112.18 & 329 \\
\hline $98032 / 4$ & Khangar & Kamchatka & 7.00 & 54.95 & 157.50 & 935 \\
\hline $80013 / 4$ & Kizimen & Kamchatka & 7.50 & 54.88 & 160.37 & 376 \\
\hline KLV5-1 & Klyuchevksoy & Kamchatka & 0.05 & 56.14 & 160.80 & 922 \\
\hline KLV5-10 & Klyuchevksoy & Kamchatka & 3.10 & 56.14 & 160.80 & 922 \\
\hline KLV5-11 & Klyuchevksoy & Kamchatka & 3.20 & 56.14 & 160.80 & 922 \\
\hline KLV5-12 & Klyuchevksoy & Kamchatka & 3.40 & 56.14 & 160.80 & 922 \\
\hline KLV5-13 & Klyuchevksoy & Kamchatka & 3.60 & 56.14 & 160.80 & 922 \\
\hline KLV5-15 & Klyuchevksoy & Kamchatka & 4.70 & 56.14 & 160.80 & 922 \\
\hline KLV5-18a & Klyuchevksoy & Kamchatka & 5.70 & 56.14 & 160.80 & 922 \\
\hline KLV5-22 & Klyuchevksoy & Kamchatka & 7.30 & 56.14 & 160.80 & 922 \\
\hline KLV5-3 & Klyuchevksoy & Kamchatka & 1.00 & 56.14 & 160.80 & 922 \\
\hline KLV5-5 & Klyuchevksoy & Kamchatka & 1.60 & 56.14 & 160.80 & 922 \\
\hline KLV5-6 & Klyuchevksoy & Kamchatka & 2.30 & 56.14 & 160.80 & 922 \\
\hline KLV5-7 & Klyuchevksoy & Kamchatka & 2.60 & 56.14 & 160.80 & 922 \\
\hline KLV5-8 & Klyuchevksoy & Kamchatka & 2.70 & 56.14 & 160.80 & 922 \\
\hline KLV5-9 & Klyuchevksoy & Kamchatka & 2.80 & 56.14 & 160.80 & 922 \\
\hline $8880 / 5$ & Ksudach & Kamchatka & 1.80 & $51.87^{\mathrm{a}}$ & $157.53^{\mathrm{a}}$ & 318 \\
\hline $8889 / 2$ & Ksudach & Kamchatka & 6.40 & $51.87^{\mathrm{a}}$ & $157.53^{\mathrm{a}}$ & 318 \\
\hline
\end{tabular}


Table 2

$\mathrm{D}(\% \mathrm{~V}, \mathrm{VSMOW})$ (pre and post magmatic correction) and wt. $\% \mathrm{H}_{2} \mathrm{O}_{\mathrm{t}}$ of water extracted from glass for each sample

\begin{tabular}{|c|c|c|c|c|c|c|c|c|}
\hline Sample Name & Volcano & Age (ka) & composition & $\begin{array}{c}\text { number } \\
\text { analyses }\end{array}$ & $\mathrm{D}(\%)$ & s.d. & $\mathrm{H}_{2} \mathrm{O}_{\mathrm{t}}(\mathrm{wt} . \%)$ & s.d. \\
\hline $99163 / 9$ & Avachinsky & 3.50 & basaltic andesite & 3 & -112 & 2.2 & 0.25 & 0.02 \\
\hline $99201 / 1$ & Avachinsky & 7.15 & andesite & 3 & -95 & 3.5 & 1.42 & 0.26 \\
\hline VF-74-200 & Fuego & 0.04 & basalt & 3 & -86 & 3.7 & 0.22 & 0.01 \\
\hline VF-74-45 & Fuego & 0.04 & basalt & 3 & -86 & 6.4 & 0.07 & 0.01 \\
\hline 808 KAR 4 & Karymsky & 7.90 & dacite & 3 & -141 & 1.6 & 3.39 & 0.07 \\
\hline Margomulyo-1p & Kelud & 0.00 & basaltic andesite & 2 & -69 & 7.1 & 0.05 & 0.01 \\
\hline Campling-4p & Kelud & 0.00 & basaltic andesite & 3 & -73 & 1.6 & 0.05 & 0.01 \\
\hline $98032 / 4$ & Khangar & 7.00 & dacite & 3 & -138 & 0.7 & 2.19 & 0.05 \\
\hline $80013 / 4$ & Kizimen & 7.50 & andesite & 2 & -129 & 0.2 & 3.16 & 0.21 \\
\hline KLV5-1 & Klyuchevksoy & 0.05 & basaltic andesite & 4 & -88 & 4.5 & 0.28 & 0.02 \\
\hline KLV5-10 & Klyuchevksoy & 3.10 & basaltic andesite & 4 & -95 & 2.8 & 0.59 & 0.01 \\
\hline KLV5-11 & Klyuchevksoy & 3.20 & basaltic andesite & 6 & -109 & 3.7 & 0.43 & 0.07 \\
\hline KLV5-12 & Klyuchevksoy & 3.40 & basaltic andesite & 3 & -100 & 4.7 & 0.42 & 0.05 \\
\hline KLV5-13 & Klyuchevksoy & 3.60 & basaltic andesite & 3 & -105 & 0.0 & 0.25 & 0.00 \\
\hline KLV5-15 & Klyuchevksoy & 4.70 & basalt & 4 & -93 & 5.6 & 1.03 & 0.02 \\
\hline KLV5-18a & Klyuchevksoy & 5.70 & basaltic andesite & 2 & -92 & 1.9 & 0.45 & 0.02 \\
\hline KLV5-22 & Klyuchevksoy & 7.30 & basaltic andesite & 4 & -93 & 2.2 & 0.64 & 0.03 \\
\hline KLV5-3 & Klyuchevksoy & 1.00 & basaltic andesite & 4 & -85 & 6.8 & 0.39 & 0.04 \\
\hline KLV5-5 & Klyuchevksoy & 1.60 & basaltic andesite & 6 & -87 & 1.4 & 0.40 & 0.03 \\
\hline KLV5-6 & Klyuchevksoy & 2.30 & basaltic andesite & 3 & -95 & 1.7 & 0.29 & 0.01 \\
\hline KLV5-7 & Klyuchevksoy & 2.60 & basaltic andesite & 6 & -103 & 3.0 & 0.45 & 0.06 \\
\hline KLV5-8 & Klyuchevksoy & 2.70 & basaltic andesite & 4 & -91 & 0.0 & 0.30 & 0.00 \\
\hline KLV5-9 & Klyuchevksoy & 2.80 & basaltic andesite & 2 & -94 & 3.1 & 0.34 & 0.02 \\
\hline $8880 / 5$ & Ksudach & 1.80 & dacite & 1 & -122 & 0.0 & 3.35 & 0.00 \\
\hline $8889 / 2$ & Ksudach & 6.40 & dacite & 3 & -116 & 2.0 & 1.66 & 0.13 \\
\hline
\end{tabular}


Table 3

$\underline{\text { Relative vesicularity and percent microlites of glass samples }}$

\begin{tabular}{|c|c|c|c|c|}
\hline Sample Name & Volcano & Age (ka) & $\begin{array}{c}\text { Relative } \\
\text { vesicularity }(1-10)\end{array}$ & Microlites (\%) \\
\hline $99163 / 9$ & Avachinsky & 3.50 & 2 & 1 \\
\hline $99201 / 1$ & Avachinsky & 7.15 & 3 & 5 \\
\hline VF-74-200 & Fuego & 0.04 & 10 & 15 \\
\hline VF-74-45 & Fuego & 0.04 & 10 & 15 \\
\hline 808 KAR 4 & Karymsky & 7.90 & 8 & 0 \\
\hline Margomulyo-1p & Kelud & 0.00 & 5 & 2 \\
\hline Campling-4p & Kelud & 0.00 & 5 & 2 \\
\hline $98032 / 4$ & Khangar & 7.00 & 7 & 3 \\
\hline $80013 / 4$ & Kizimen & 7.50 & 6 & 0 \\
\hline KLV5-1 & Klyuchevksoy & 0.05 & 3 & 30 \\
\hline KLV5-10 & Klyuchevksoy & 3.10 & 2 & 35 \\
\hline KLV5-11 & Klyuchevksoy & 3.20 & 3 & 30 \\
\hline KLV5-12 & Klyuchevksoy & 3.40 & 1 & 40 \\
\hline KLV5-13 & Klyuchevksoy & 3.60 & 2 & 20 \\
\hline KLV5-15 & Klyuchevksoy & 4.70 & 4 & 35 \\
\hline KLV5-18a & Klyuchevksoy & 5.70 & 4 & 30 \\
\hline KLV5-22 & Klyuchevksoy & 7.30 & 2 & 50 \\
\hline KLV5-3 & Klyuchevksoy & 1.00 & 2 & 40 \\
\hline KLV5-5 & Klyuchevksoy & 1.60 & 2 & 20 \\
\hline KLV5-6 & Klyuchevksoy & 2.30 & 4 & 10 \\
\hline KLV5-7 & Klyuchevksoy & 2.60 & 4 & 20 \\
\hline KLV5-8 & Klyuchevksoy & 2.70 & 4 & 30 \\
\hline KLV5-9 & Klyuchevksoy & 2.80 & 4 & 20 \\
\hline $8880 / 5$ & Ksudach & 1.80 & 8 & 0 \\
\hline $8889 / 2$ & Ksudach & 6.40 & 8 & 0 \\
\hline 97KAM-03a & Kurile Lake & 7.60 & 9 & 0 \\
\hline 97KAM11 & Kurile Lake & 7.60 & 5 & 1 \\
\hline 97KAM29AL & Kurile Lake & 7.60 & 5 & 2 \\
\hline 97KAM29DL & Kurile Lake & 7.60 & 9 & 0 \\
\hline 97KAM29HW & Kurile Lake & 7.60 & 9 & 0 \\
\hline 97KAM32D1 & Kurile Lake & 7.60 & 6 & 2 \\
\hline 97KAM-21CG & Kurile Lake & 7.60 & 9 & 1 \\
\hline 97КАМ-29AB & Kurile Lake & 7.60 & 8 & 2 \\
\hline 97KAM29DB & Kurile Lake & 7.60 & 8 & 2 \\
\hline CLD205J & Llaima & 10.00 & 8 & 0 \\
\hline 2013MM-1 & Mt. Mazama & 7.70 & 7 & 0 \\
\hline 2013MM-10 & Mt. Mazama & 7.70 & 7 & 0 \\
\hline
\end{tabular}


Table 4

Textural data for BSE imaged tephra from Kurile Lake and Klyuchevskoy volcanoes in Kamchatka, Russia

\begin{tabular}{|c|c|c|c|c|c|c|c|c|}
\hline Unit & Volcano & Age (ka) & composition & Region of Clast & Area $\left(\mathrm{mm}^{2}\right)$ & $\begin{array}{c}\text { Total } \\
\text { Perimeter } \\
(\mathrm{mm})\end{array}$ & Number & $\begin{array}{c}\text { Number } \\
\text { Density } \\
\left(\mathrm{mm}^{-2}\right)\end{array}$ \\
\hline \multirow{4}{*}{ KLV5-1 } & \multirow{4}{*}{ Klyuchevskoy } & \multirow{4}{*}{0.05} & \multirow{4}{*}{ basaltic andesite } & Total Image & 34.0 & 92.8 & 1 & \multirow{4}{*}{27} \\
\hline & & & & Minerals & 0.71 & 8.08 & 7 & \\
\hline & & & & Vesicles & 15.6 & 450 & 899 & \\
\hline & & & & Glass & 17.7 & & & \\
\hline \multirow{4}{*}{ KLV5-8 } & \multirow{4}{*}{ Klyuchevskoy } & \multirow{4}{*}{2.7} & \multirow{4}{*}{ basaltic andesite } & Total & 23.7 & 63.4 & 1 & \multirow{4}{*}{28} \\
\hline & & & & Minerals & 0.72 & 7.29 & 5 & \\
\hline & & & & Vesicles & 12.1 & 248 & 650 & \\
\hline & & & & Glass & 10.9 & & & \\
\hline \multirow{4}{*}{ KLV5-22 } & \multirow{4}{*}{ Klyuchevskoy } & \multirow{4}{*}{7.3} & \multirow{4}{*}{ basaltic andesite } & Total & 24.6 & 52.6 & 1 & \multirow{4}{*}{72} \\
\hline & & & & Minerals & 1.23 & 12.4 & 13 & \\
\hline & & & & Vesicles & 13.8 & 442 & 1695 & \\
\hline & & & & Glass & 9.62 & & & \\
\hline \multirow{4}{*}{ 97KAM29AL } & \multirow{4}{*}{ Kurile Lake } & \multirow{4}{*}{7.6} & \multirow{4}{*}{ rhyolite } & Total & 36.8 & 109 & 1 & \multirow{4}{*}{736} \\
\hline & & & & Minerals & 0.16 & 3.80 & 6 & \\
\hline & & & & Vesicles & 13.1 & 2078 & 26983 & \\
\hline & & & & Glass & 23.6 & & & \\
\hline \multirow{4}{*}{ 97KAM29DB } & \multirow{4}{*}{ Kurile Lake } & \multirow{4}{*}{7.6} & \multirow{4}{*}{ basalt } & Total & 96.7 & 159 & 1 & \multirow{4}{*}{77} \\
\hline & & & & Minerals & 32.7 & 224 & 129 & \\
\hline & & & & Vesicles & 32.9 & 1447 & 4953 & \\
\hline & & & & Glass & 31.2 & & & \\
\hline \multirow{4}{*}{ 97KAM21CG } & \multirow{4}{*}{ Kurile Lake } & \multirow{4}{*}{7.6} & \multirow{4}{*}{ andesite } & Total & 31.0 & 59.4 & 1 & \multirow{4}{*}{161} \\
\hline & & & & Minerals & 4.80 & 55.0 & 35 & \\
\hline & & & & Vesicles & 9.08 & 554 & 4215 & \\
\hline & & & & Glass & 17.2 & & & \\
\hline
\end{tabular}




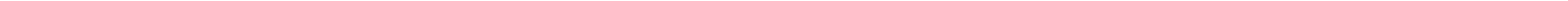


Figulkè_2 $\bigcirc$ Chile

Mafic: $\bigcirc$ Tanzania
Kamchatka

$\diamond$ Mt. Mazama

* Recent Ash

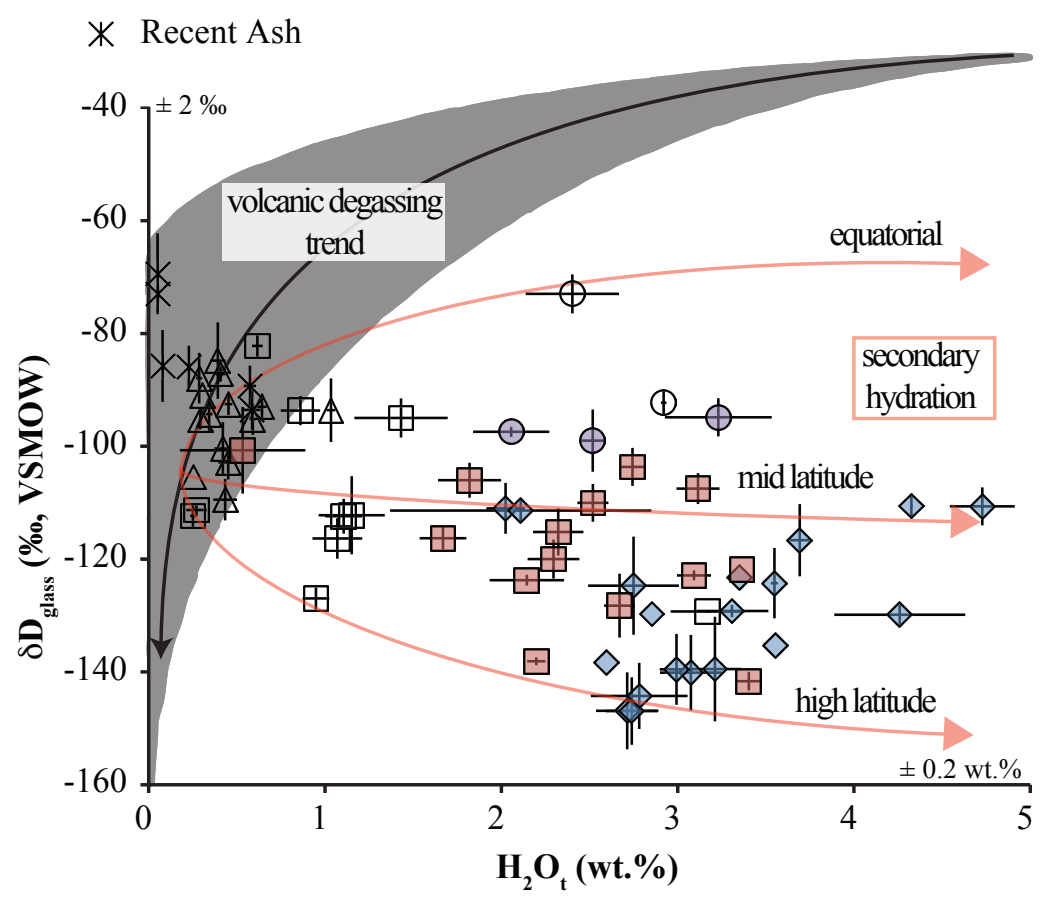

$\triangle$ Klyuchevskoy 


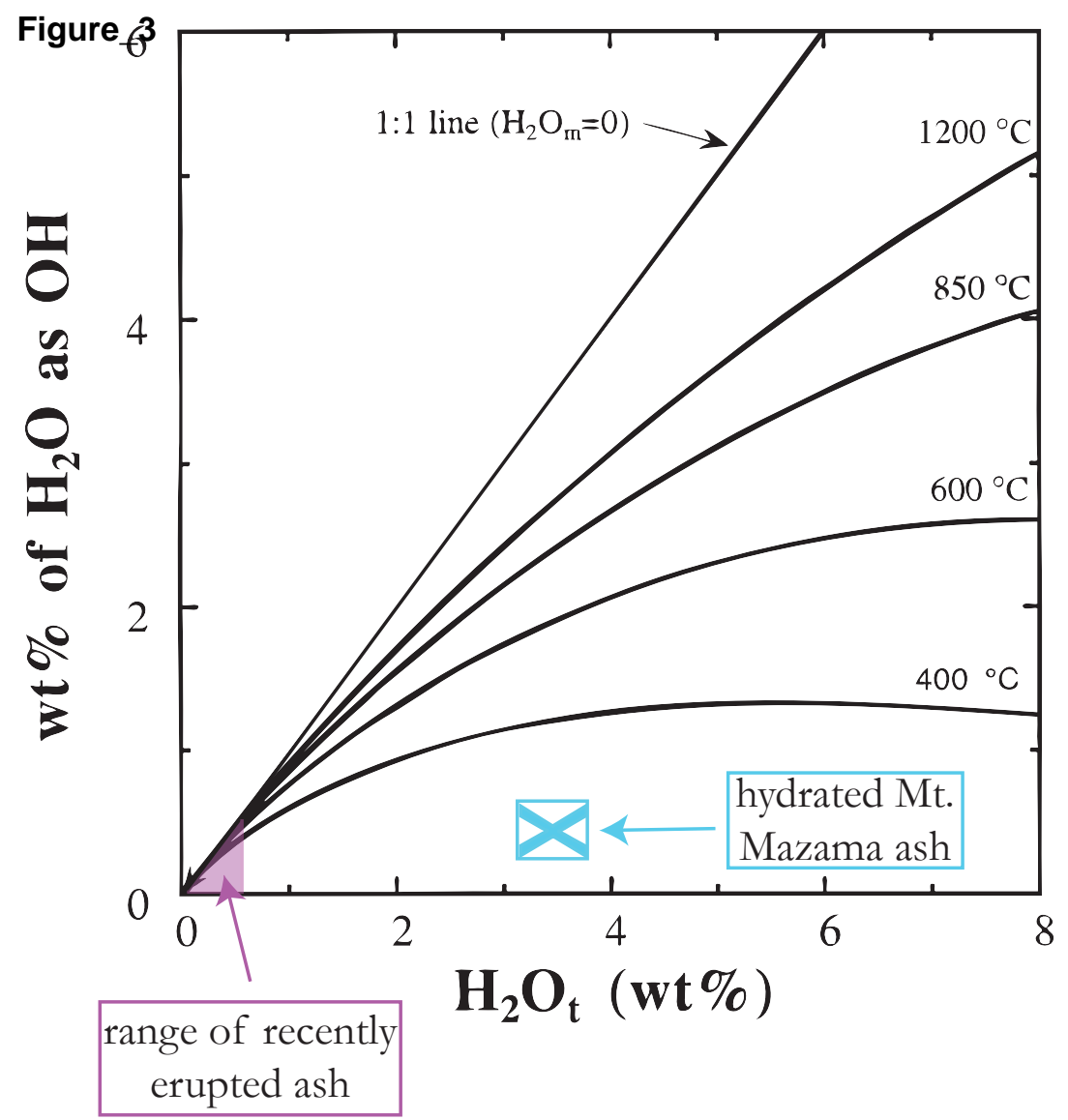


$97 K \wedge M 21 C G$

andesite
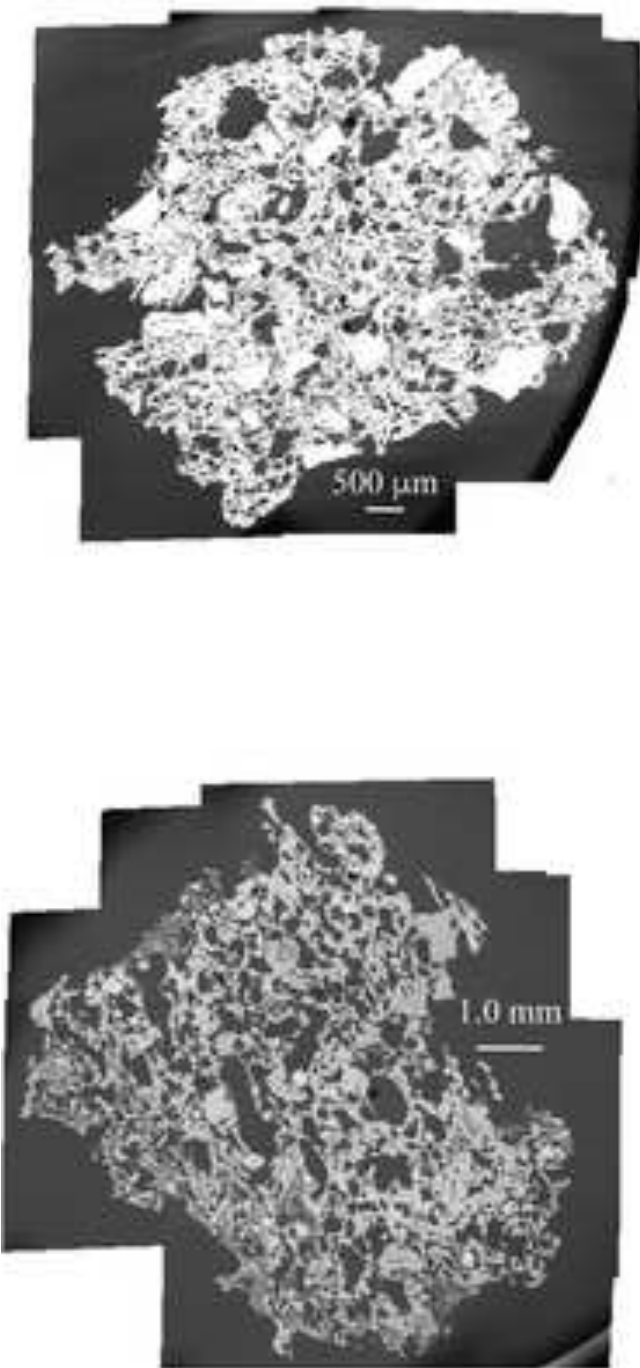

KLV5-1

basaltic andesite
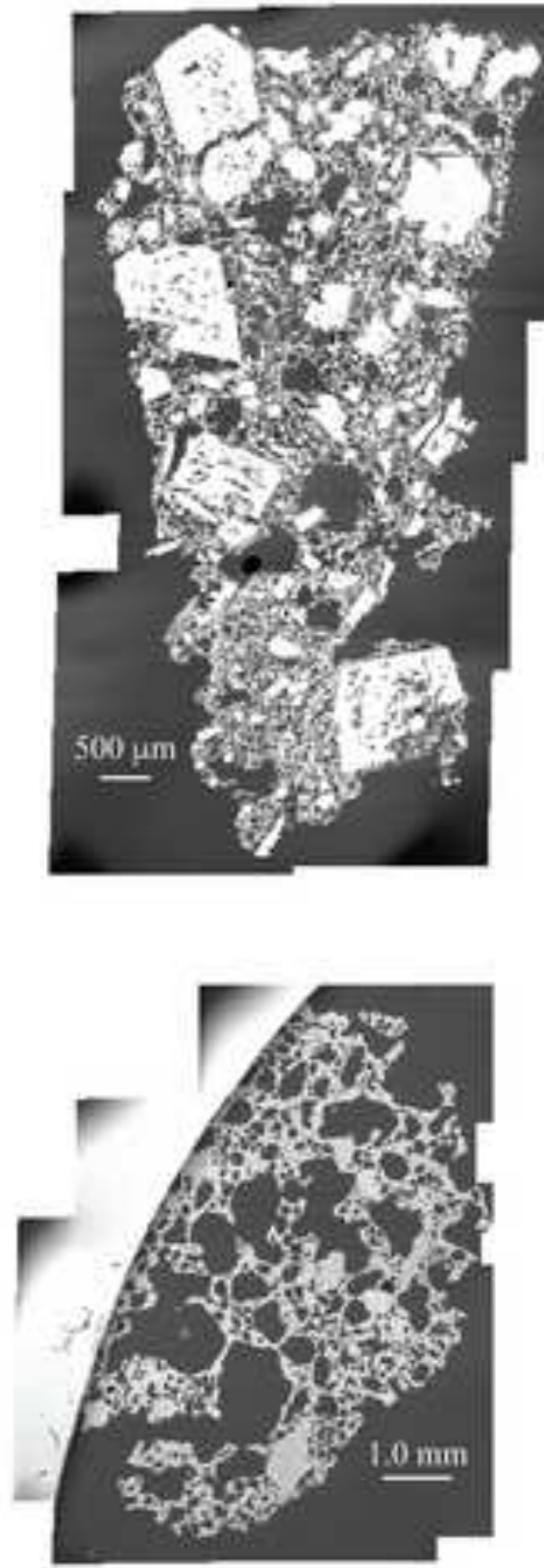

KLV5-8

basaltic andesite
97KАM29AL

rhyolite
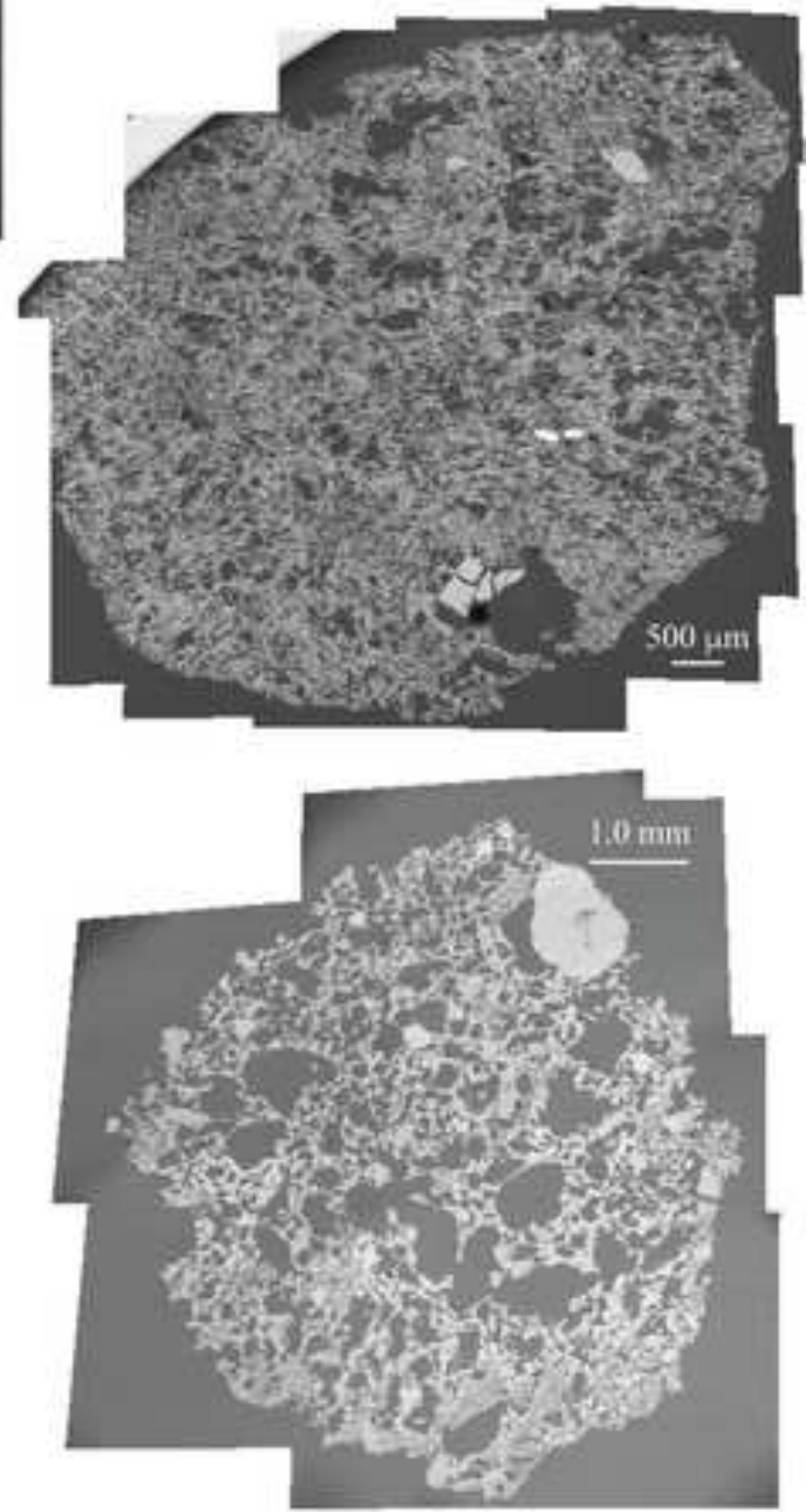

KLV5-22

basaltic andesite 

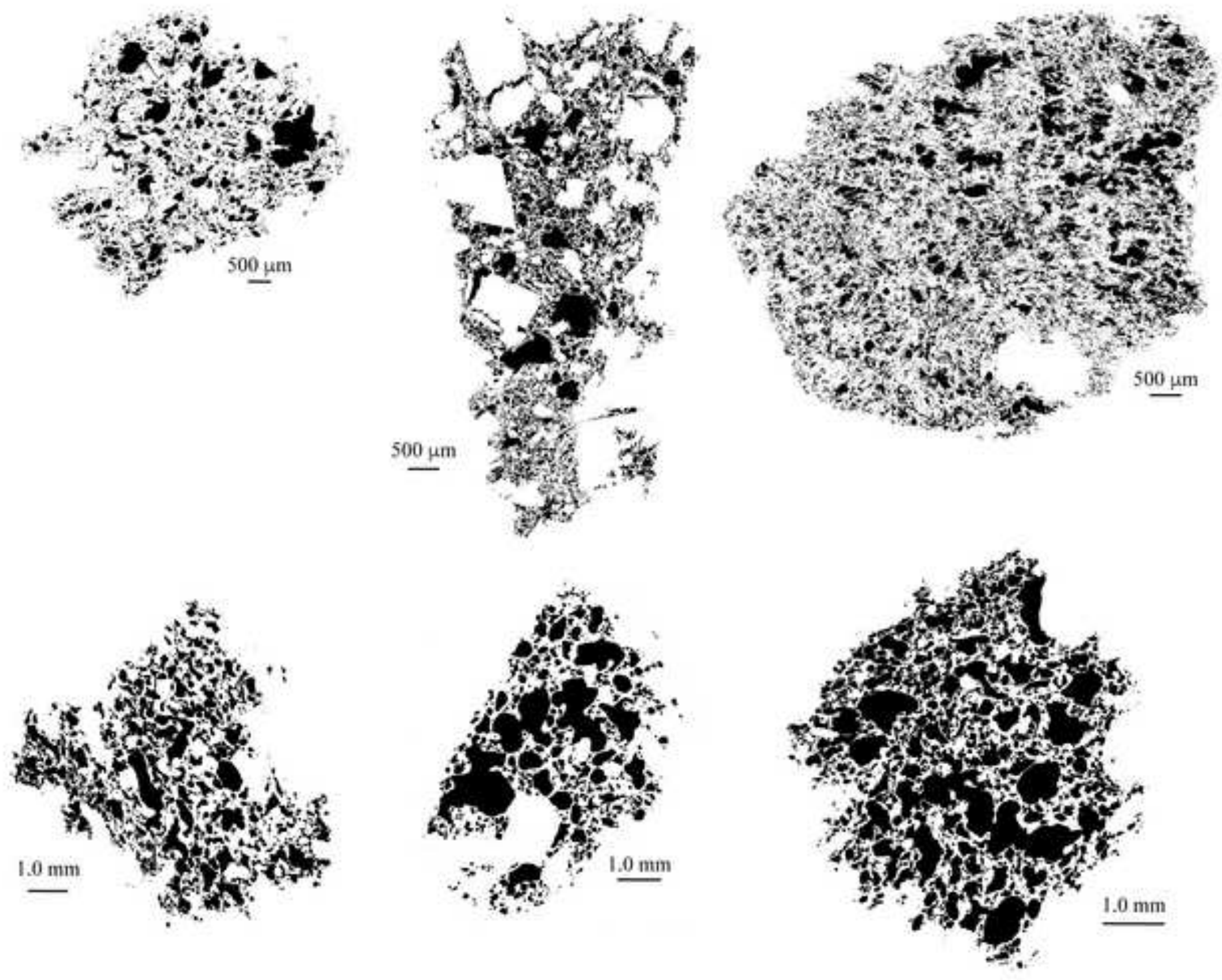


\section{$97 \mathrm{KAM} 21 \mathrm{CG}$}

4215 vesicles

Total Area $=9.115 \mathrm{~mm}^{2}$

Average Area $=0.002 \mathrm{~mm}^{2}$

Average Perimeter $=0,132 \mathrm{~mm}$
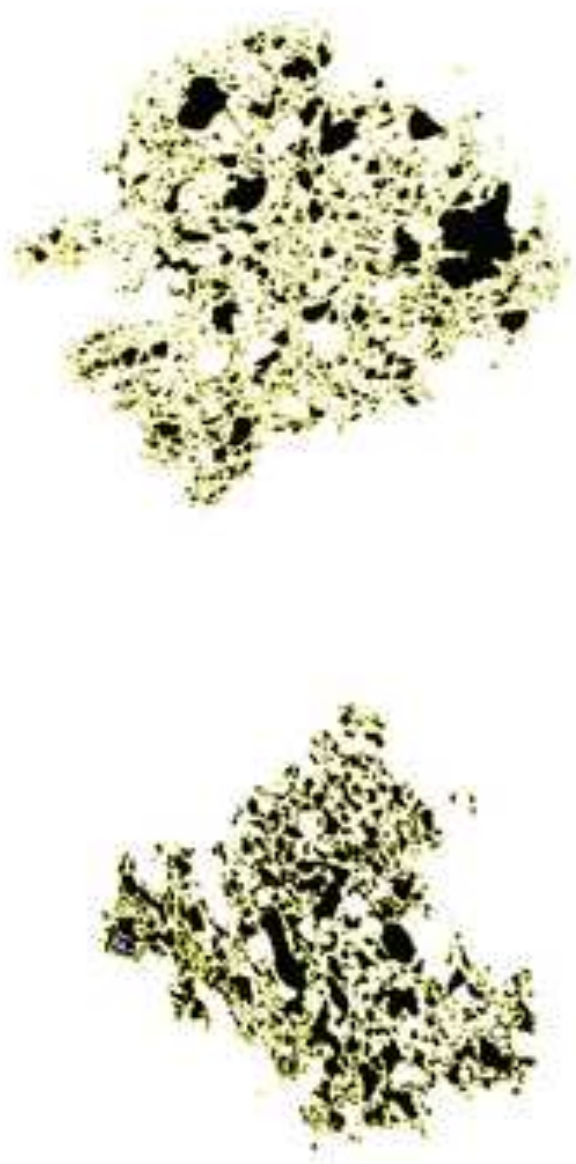

KLV5-1

898 vesicles

Total Area $=15.563 \mathrm{~mm}^{2}$

Average Area $=0.017 \mathrm{~mm}^{2}$

Average Perimeter $=0.501 \mathrm{~mm}$

\section{KAM29DB}

4953 vesicles

Total Area $=32.962 \mathrm{~mm}^{2}$

Average Area $=0.007 \mathrm{~mm}^{2}$

Average Perimeter $=0.292 \mathrm{~mm}$
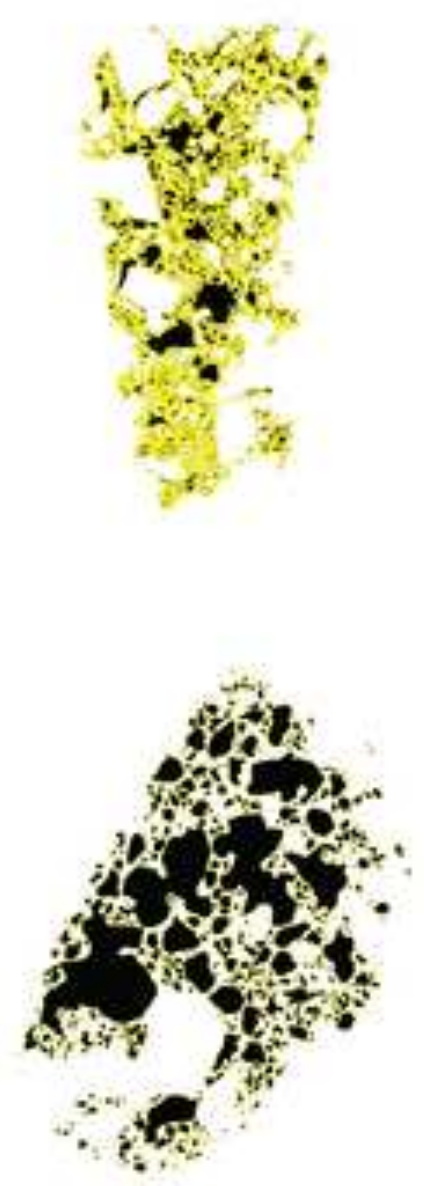

KLV5-8

650 vesicles

Total Area $=12.123 \mathrm{~mm}^{2}$

Average Area $=0.019 \mathrm{~mm}^{2}$

Average Perimeter $=0.381 \mathrm{~mm}$
97KAM29AL

26983 vesicles

Total $A$ rea $=13.146 \mathrm{~mm}^{2}$ Average Area $=0.0004872 \mathrm{~mm}^{2}$ Average Perimeter $=0,077 \mathrm{~mm}$
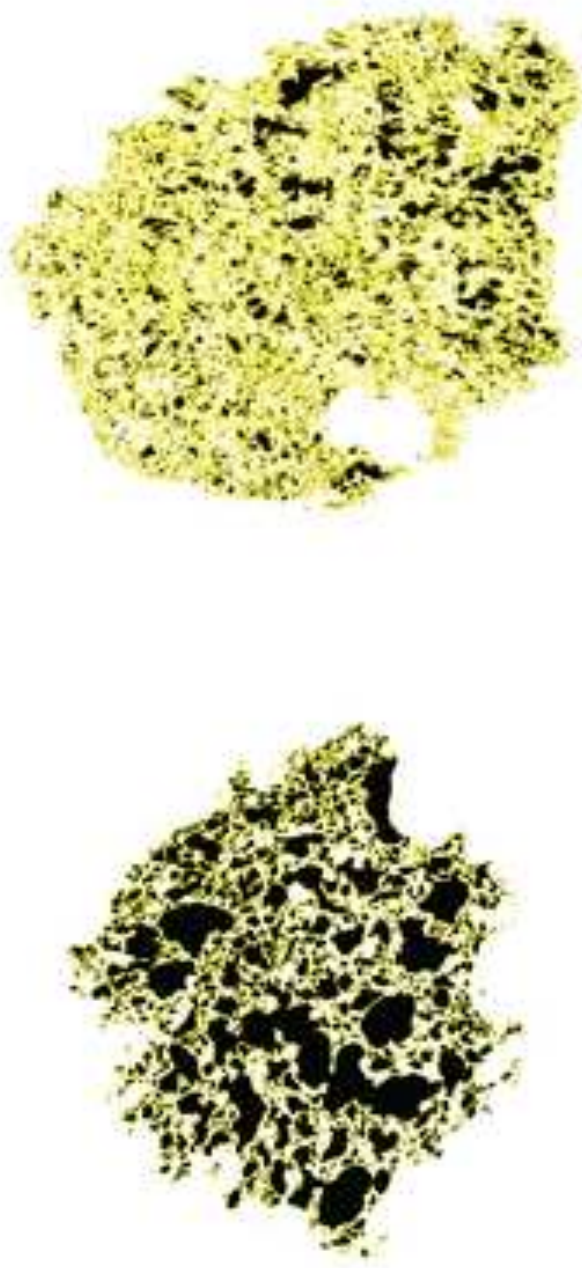

KLV5-22

1669 vesicles

Total Area $=14.041 \mathrm{~mm}^{2}$ Average Area $=0.008 \mathrm{~mm}^{2}$ Average Perimeter $=0.269 \mathrm{~mm}$ 
Figure $* \bar{Z}_{\text {or }} \delta D_{\text {glass }}$ of $-135 \%$

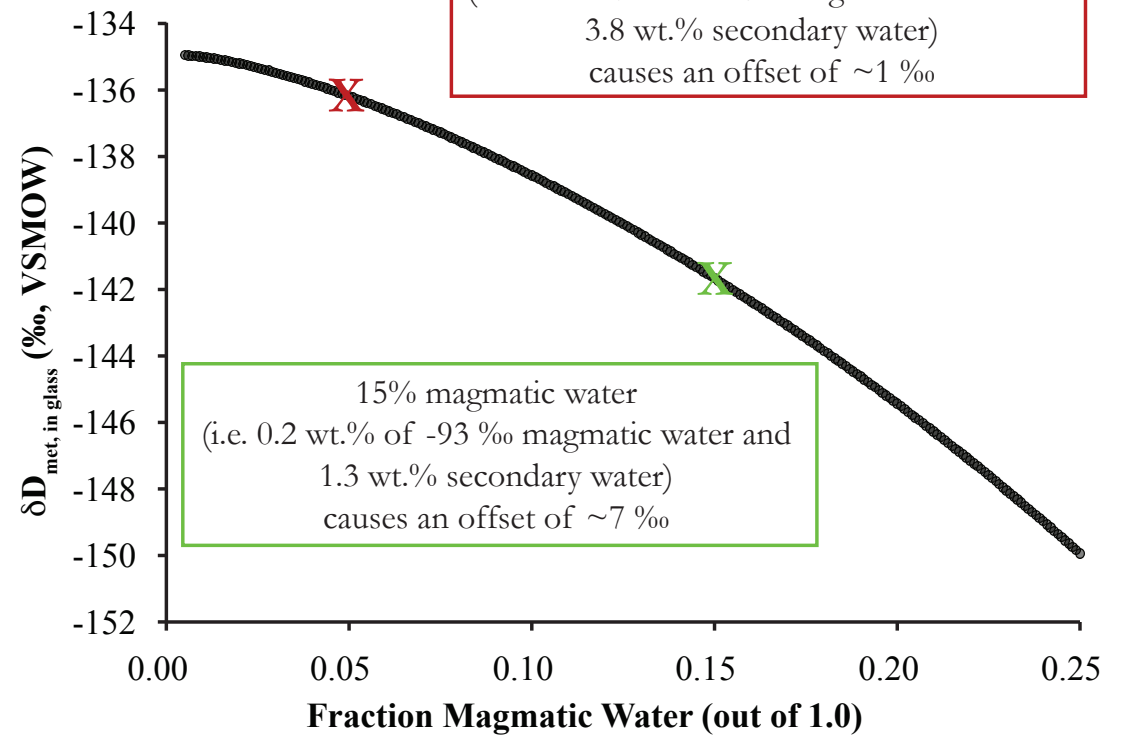


Figluse: $80 \quad$ Chile $\quad \square$ Kamchatka

$\left(11^{\circ} \mathrm{C} / 2000 \mathrm{~mm}\right) \quad\left(5^{\circ} \mathrm{C} / 1000 \mathrm{~mm}\right)$

Mafic : $\bigcirc$ Tanzania

$\left(23^{\circ} \mathrm{C} / 600 \mathrm{~mm}\right)$ $\square$ Kamchatka

$\left(5^{\circ} \mathrm{C} / 1000 \mathrm{~mm}\right)$

* Recent Ash $\diamond$ Mt. Mazama

$\left(8{ }^{\circ} \mathrm{C} / 1000 \mathrm{~mm}\right)$

$\triangle$ Klyuchevskoy

$\left(5^{\circ} \mathrm{C} / 1000 \mathrm{~mm}\right)$

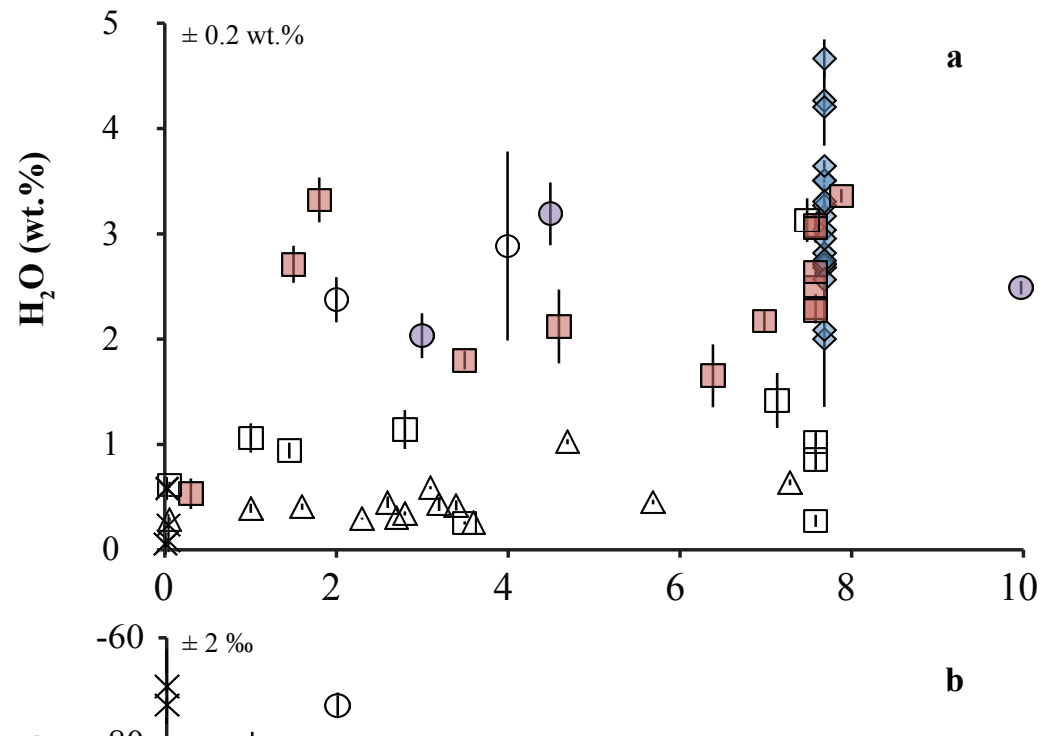

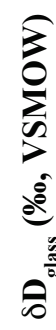<smiles>[Mg][Mg][Mg]</smiles>

$4 \Delta$

$-100$

$\triangle \Delta A \Delta \phi$ of $\triangle$

फ口
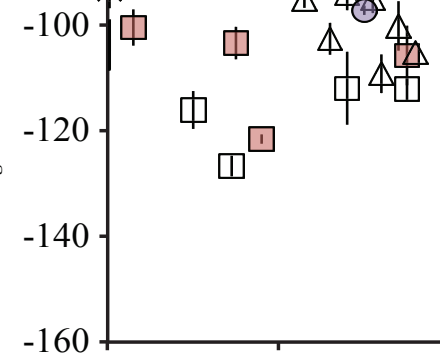

$\square^{2}$

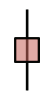

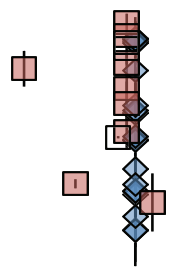

0

2

4

6

8 
Figutereis $\circ$ Chile $\square$ Kamchatka $\diamond$ Mt. Mazama

Mafic: $\bigcirc$ Tanzania $\square$ Kamchatka $\triangle$ Klyuchevskoy * Recent Ash $\diamond$ published Mt. Mazama (felsic)
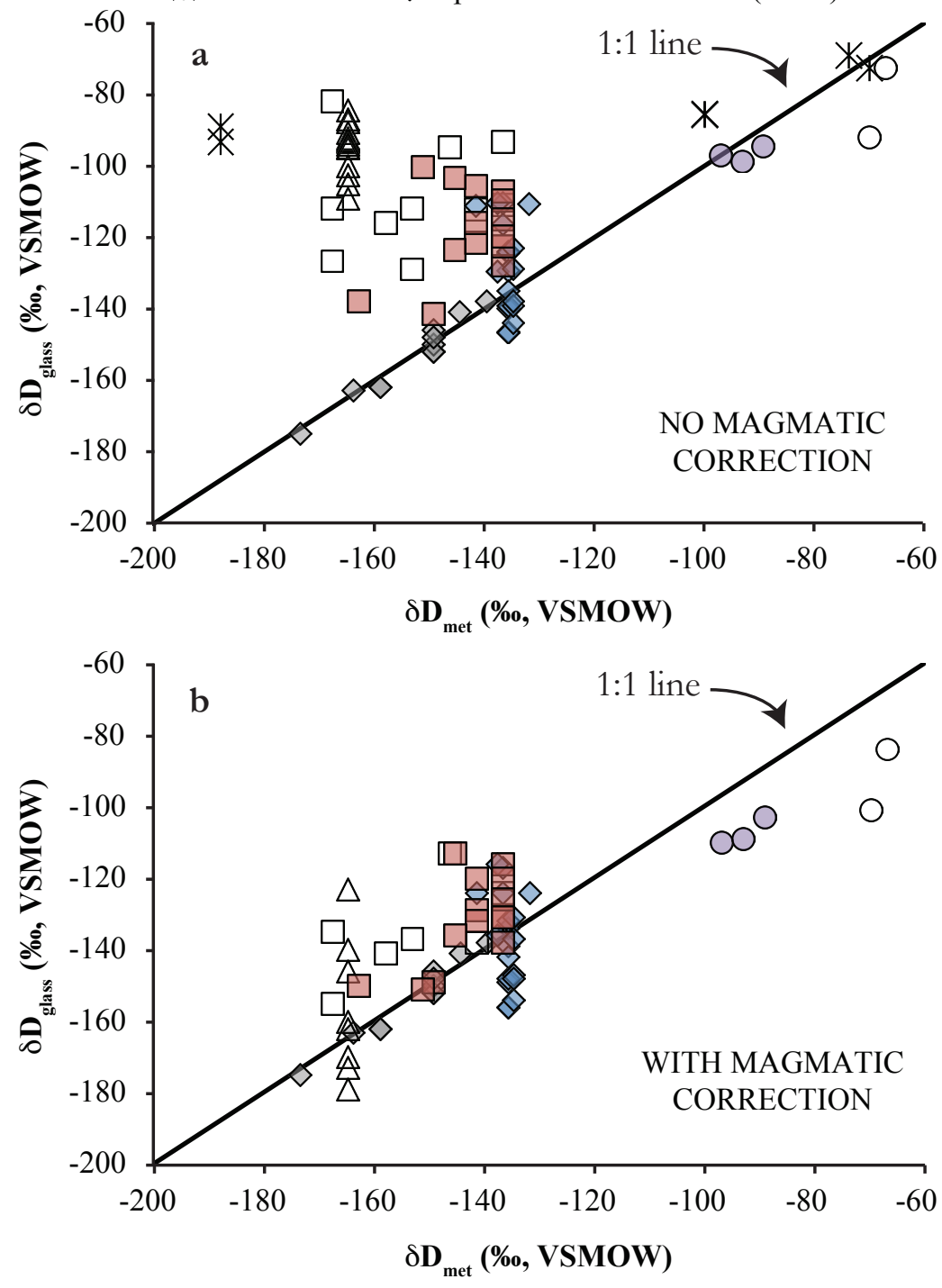
Figtuteict0 $\bigcirc$ Chile

Mafic: $\bigcirc$ Tanzania $\square$ Kamchatka $\triangle$ Klyuchevskoy
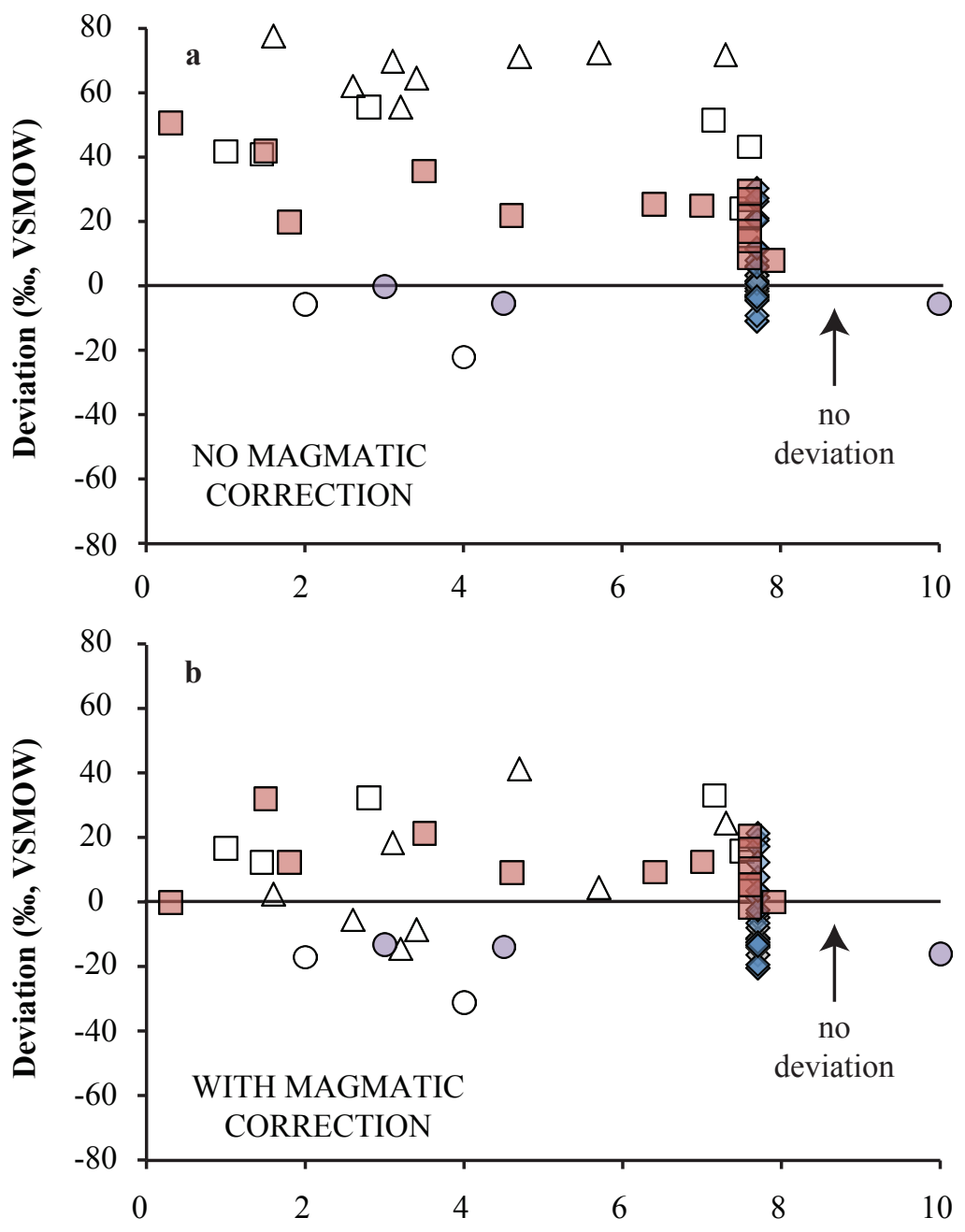

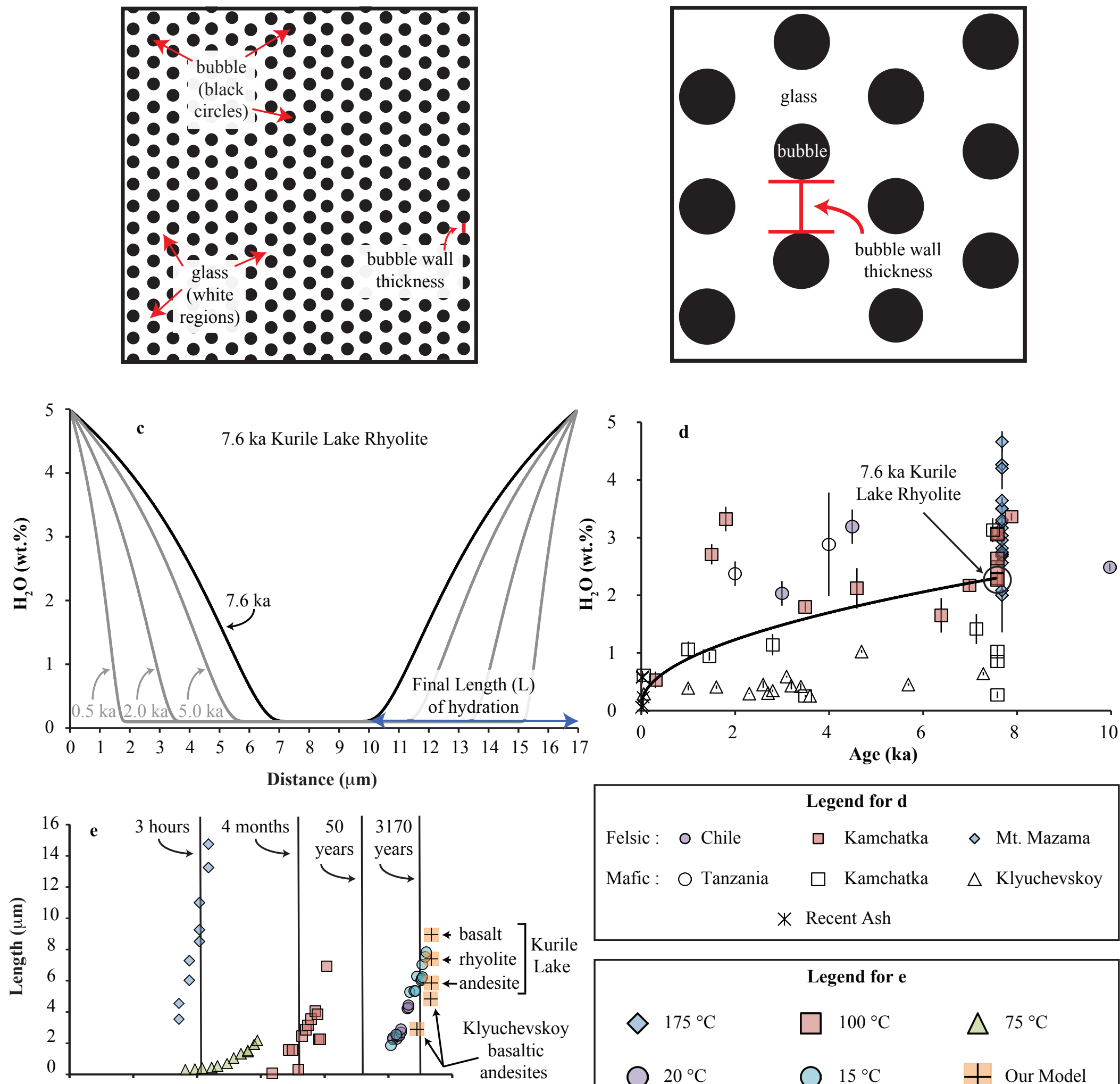

$1 \mathrm{E}+00 \quad 1 \mathrm{E}+02 \quad 1 \mathrm{E}+04 \quad 1 \mathrm{E}+06 \quad 1 \mathrm{E}+08 \quad 1 \mathrm{E}+10 \quad 1 \mathrm{E}+12$

Time (seconds)

\section{Legend for $d$}

$\begin{array}{ccc}\text { Felsic : } \bigcirc \text { Chile } & \square \text { Kamchatka } & \diamond \text { Mt. Mazama } \\ \text { Mafic : } \bigcirc \text { Tanzania } & \square \text { Kamchatka } \triangle \text { Klyuchevskoy } \\ & * \text { Recent Ash }\end{array}$

\begin{tabular}{|lll|}
\hline \multicolumn{4}{c|}{ Legend for e } \\
$\diamond 175^{\circ} \mathrm{C}$ & $\square 100^{\circ} \mathrm{C}$ & $\triangle 75^{\circ} \mathrm{C}$ \\
$\bigcirc 20^{\circ} \mathrm{C}$ & $\bigcirc 15^{\circ} \mathrm{C}$ & 十 Our Model
\end{tabular}


Figure $_{\text {Felsic }}$ : $\bigcirc$ Chile $\square$ Kamchatka $\diamond$ Mt. Mazama

FELSIC
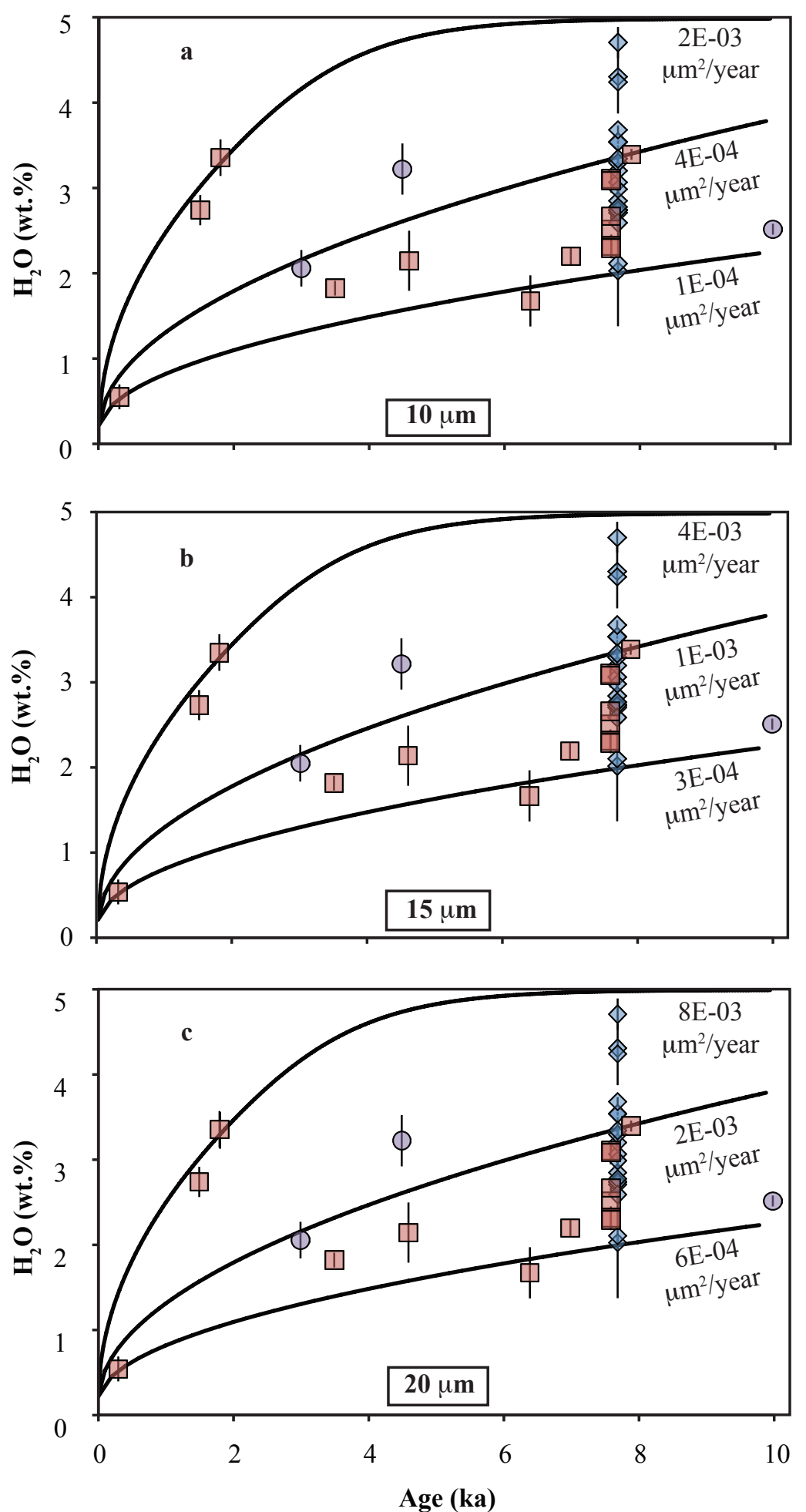

Mafic: $\square$ Kamchatka $\triangle$ Klyuchevskoy

MAFIC
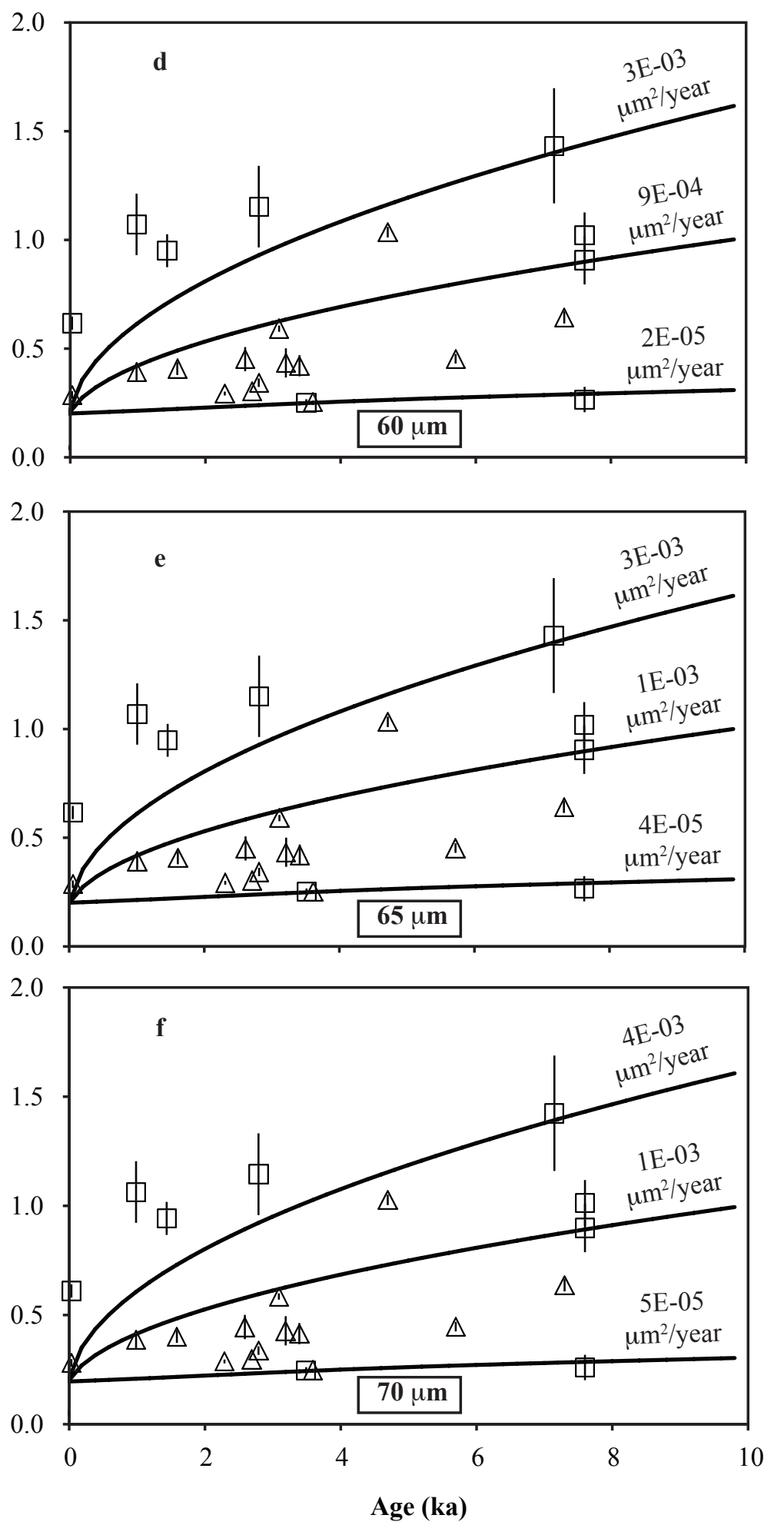
Figure_13

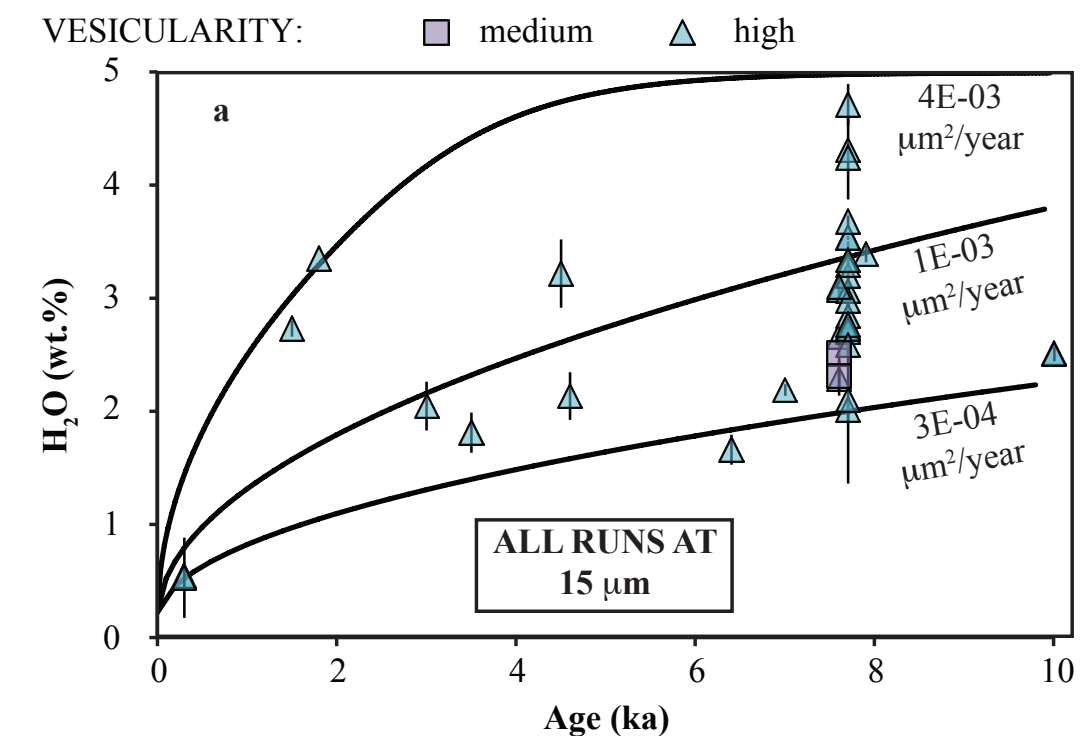

MAFIC

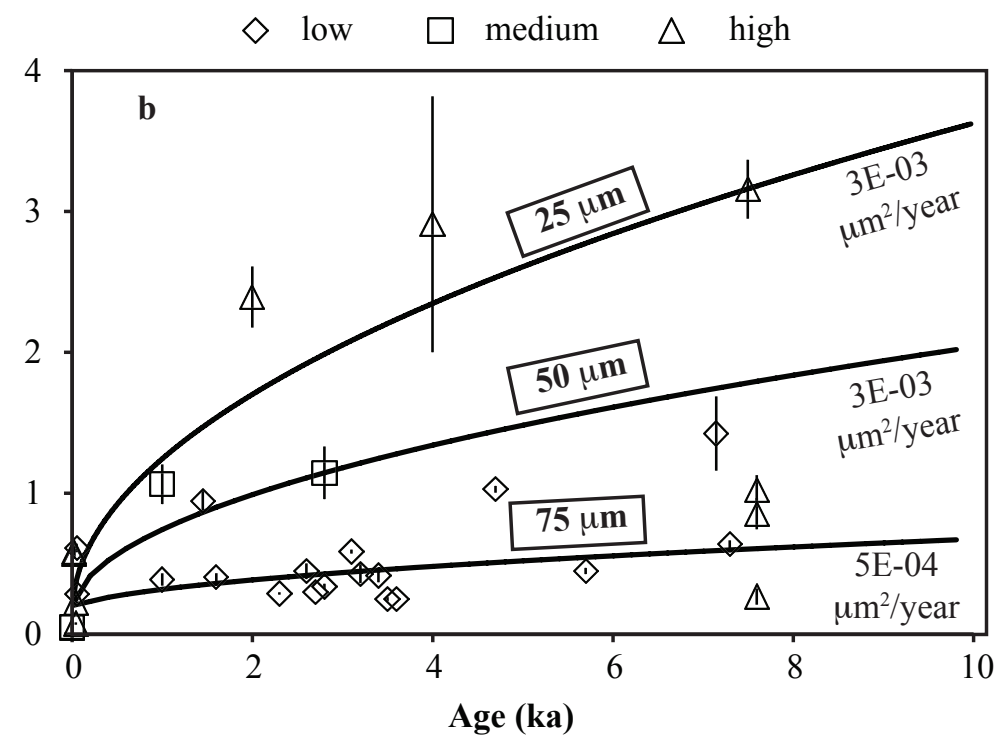


Mafic: $\bigcirc$ Tanzania $\square$ Kamchatka $\triangle$ Klyuchevskoy

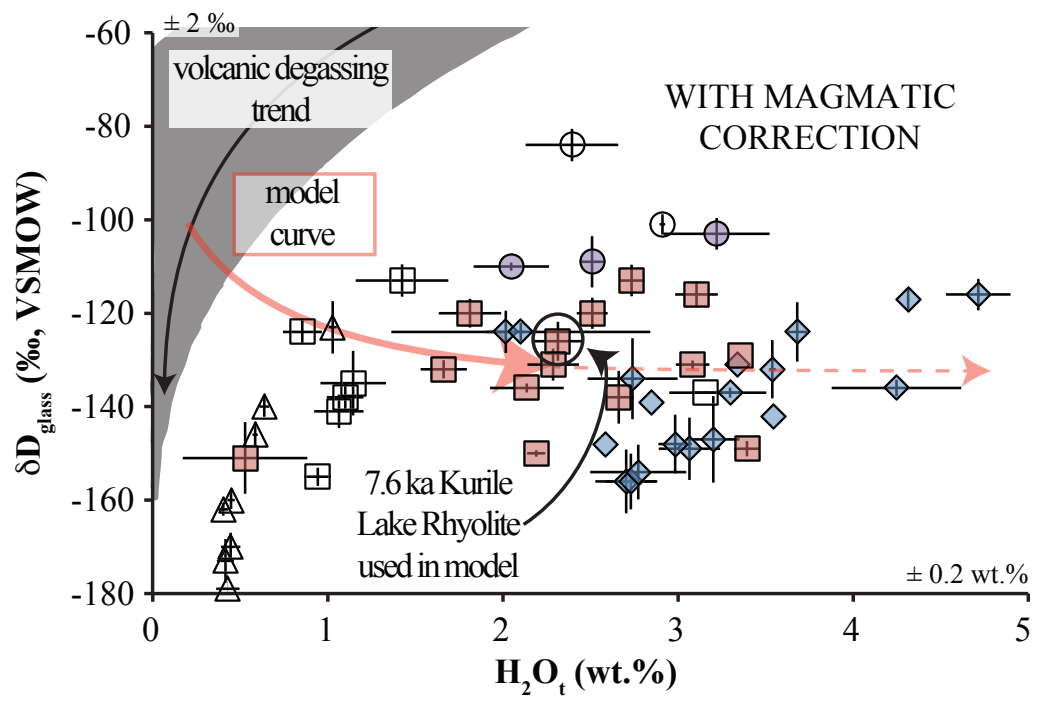

